\title{
RECENT JUdiCIAL DEVELOPMENTS OF INTEREST TO OIL AND GAS LAWYERS
}

\author{
Mark houston," Thomas P. Donovan, Q.C.", \\ ROBERT W. CaRMICHAEL"“ AND BRANDON BARNES
}

This article is intended to provide a bricf review of recent Canadian judicial decisions of interest to oil and gas lawyers. The awhors have surveyed Canadian case lan in the areas of govermment regulation. conflicts, creditor's rights, surface rights, contract. tax, and other areas. Portions of many of these summaries have previously been published in the Cox Hanson O'Reilly Matheson Oil \& Gas Netletter on the Quicklaw service operated by LexisNeris Canada Inc.
Cet aricle a pour bu de donner un bref aperçu des recentes decisions judiciaires intéressam les avocats du domaine pitrolier et gazier. Les auteurs ont examine la jurisprudence canadienne dans les domaines de la riglementation gouvernementale, des conflits, des droits des crianciers, des droits de superficie, des comtrats, de l'impöt et autres. Des portions de plusieurs de cess sommaires ont été publices dans le bulletin Cor Manson OReilly. Matheson Oil \& Gas sur le service de Quicklan. exploite par LexisNexix Canoda lnc.

\section{TABLE OF CONTENTS}

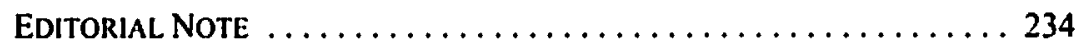

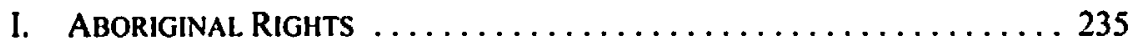

A. HAIDA NATION V. BRITISH COLUMBIA (MINISTER OF FORESTS) . . . 235

B. TAKU RIVER TLINGIT FIRST NATION V. BRITISH COLUMBIA

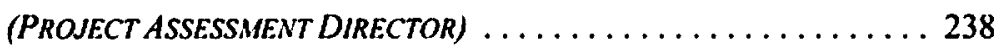

II. Administrative LAW . . . . . . . . . . . . . . . . . 239

A. ALLIANCE PIPEIINE V. ALBERTA (MINISTER OF

MUNICIPAL AFFAIRS) . .................... 239

B. MARITIME \& NORTHEAST PIPEIINE LLP V. ELLIOTT ........ 241

C. ALBERTA ENERGY V. GOODWELL PETROLEUM CORP. LTD. . . . . 242

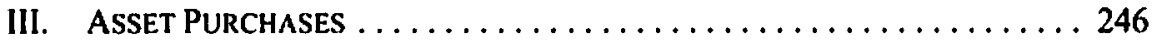

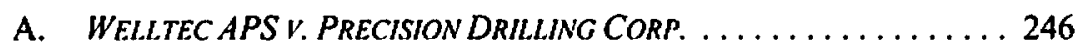

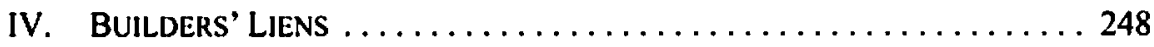

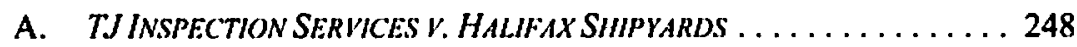

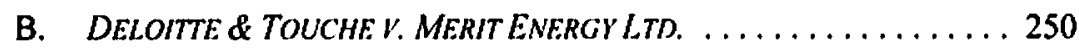

V. CONFIDENTIAL INFORMATION $\ldots \ldots \ldots \ldots \ldots \ldots \ldots \ldots \ldots \ldots \ldots \ldots \ldots \ldots \ldots$

A. HUSKY OLL OPERATIONS LTD. V.

ANADARKO CANADA CORP. ..................... 253

VI. CONTRACTS ............................. 255

A. PURE ENERG MARKETING LTD. V. RAMARRO RESOURCES ...... 255

B. C.D. OLL WELL SERVICING LTD. V.

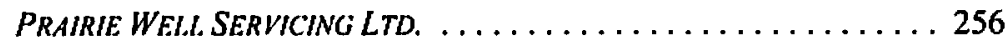

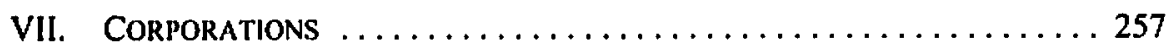

A. PEOPLES DEPARTMANT STORES (TRUSTEE OF) V. WISE _...... 257

VIII. Damages .............................. 260

A. Amoco Canada PEtroleum v. Propak Sustems LTD. ....... 260 
B. MONTREAI. TRUST V. WILLISTON WIIDCATTERS CORP. . . . . . . . 262

IX. EASEMENTS . . . . . . . . . . . . . . . . . . . . . 264

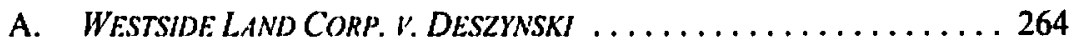

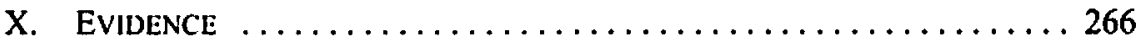

A. MOSAID TECHNOLOGIES V. SAMSUNG ELECTRONICS . . . . . . 266

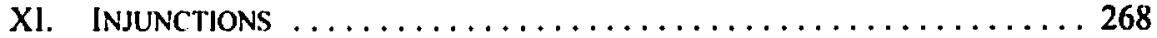

A. ANDROSCOGGEN ENFRGY LLCV V.

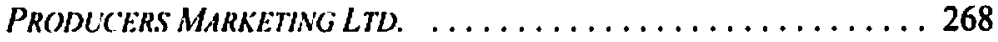

B. DASTOUS V. CANADIAN NATURAI. RESOURCES LTD. . . . . . 270

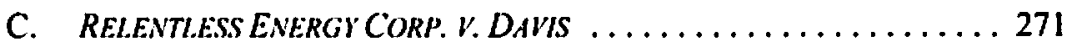

XII. JoInt VentuRES $\ldots \ldots \ldots \ldots \ldots \ldots \ldots \ldots \ldots \ldots \ldots \ldots \ldots \ldots \ldots$

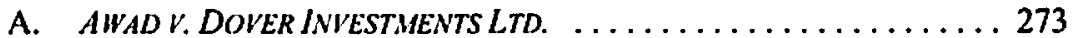

B. DIRECT ENERGY MARKETING LIMITED V.

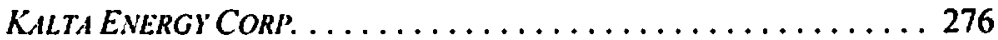

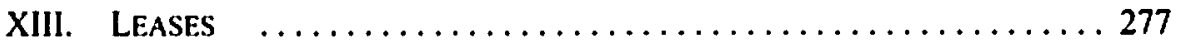

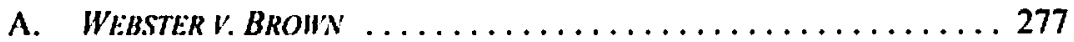

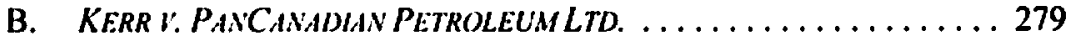

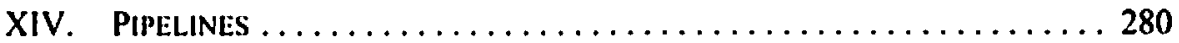

A. TRansCanada PIJELJNes Lto. $V$.

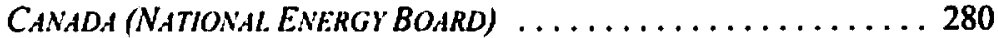

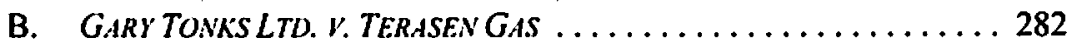

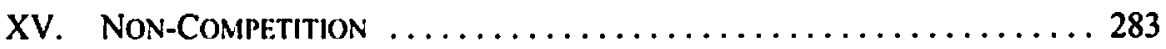

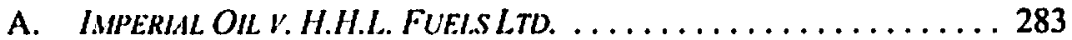

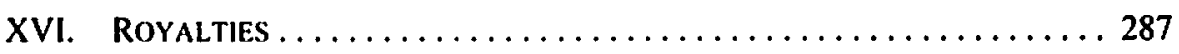

A. JAMES H. MEEK TRUST (TRUSTHE OF) $v$.

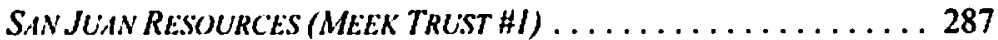

B. JAMES H. MFEK ESTATE V. SAN JUAN RESOURCES

(MEEK TRUST \#2) . . . . . . . . . . . . . . . . . 290

C. R. W. MITTEN ENTERPRISES V.

COMPUTERSHARE TRUST COMPANY OF CANADA ......... 291

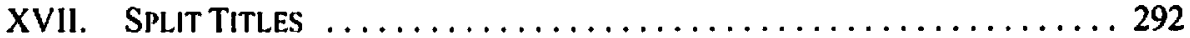

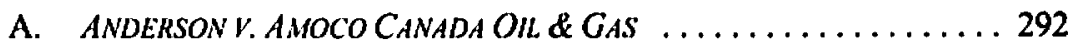

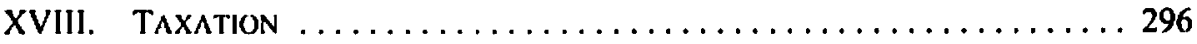

A. IRVING OUI. V. NHW BRUNSWICK

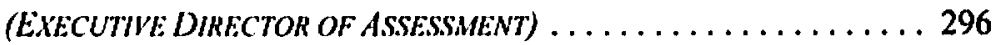

\section{EDITORIAL NOTE}

In the interest of brevity, we have shortened the number of cases considered in this article, giving consideration to other topics discussed in this issue of the Review. The significant regulatory decisions of Paramount Energy Operating Corp. v. Alberta (Energy and Utilities Board), 'EnCana Corp. v. Alberta (Energy and Utilities Board), ${ }^{2}$ and BP Canada Energy Co. 
v. Alberla (Energy and Uitities Board), ${ }^{3}$ are explored in "Recent Regulatory and Legislative Developments of Interest to Oil and Gas Lawyers," prepared by John Gruber.

\section{Aboriginal Rights}

\section{A. HAIDA NATION V. BRITISH COLUMBIA (MINISTER OF FORESTS) \\ I. FACTS}

The Haida people claim title to all the lands of Haida Gwaii (The Queen Charlotte Islands) and all the waters surrounding it. This claim, despite lacking legal recognition, is generally regarded as being a strong one, as the Haida were the original inhabitants of the islands, and have claimed title for over a century. There is little historical debate as to the merits of their association with the asserted territory. The Crown, in the form of the province of British Columbia and the federal government, were engaged in a process of settling the claim through negotiations throughout the time-period relevant to this decision.

The Government of British Columbia has title to the land, and has granted numerous treefarm licences (TFLs, or licences for logging) on the islands, beginning in the 1930s. The Haida people, though not always availing themselves of strictly judicial mechanisms, have opposed the practice since it began. In January 2000, the Haida launched a lawsuit objecting to the transfer of TFL 39 to Weyerhaeuser. They argued that, as their claim to title was in the process of negotiation and settlement, authority to grant the licence was at issue. The Haida were concerned that they would lose forests - a vital component to their cultural identity and economic sustenance - in the interim period before the title was settled.

This landmark decision provided a response to the question of how the Crown and private enterprise are to handle consultation obligations, if indeed any exist, with Aboriginal stakeholders whose specific claims have not been settled or are in the process of settlement. At trial, the judge dismissed an application by the Haida to have the TFL transfer set aside pending the outcome of settlement negotiations, but accepted that the Crown had a moral, as opposed to a legal, obligation to consult the Haida people. The Court of Appeal overtumed this decision, ruling the Crown, and Weyerhaeuser itself, have an obligation to consult and, if possible, accommodate the concerns of the Haida, or any people whose claims are not settled or are in the process of settlement. The issue, held the Court of Appeal, was one of notice: if the claim is established, known, and supported by the members of the group claiming title, some degree of consultation is necessary in discharging one's legal and moral duties. Weyerhaeuser and the Crown appealed to the Supreme Court of Canada. 


\section{DECISION AND ANALYSIS}

The Court allowed Weyehacuser's appeal, but upheld the obligation on the Crown to consult and accommodate if possible. Chief Justice McLachlin, in a concise judgment written for the bench as a whole, produced an authoritative answer to the question of how the Crown and unsettled parties claiming title ought to interact. The federal and provincial governments, she wrote, have a duty to consult with Aboriginal peoples that is rooted firmly in the honour of the Crown. The obligation to act honourably is necessary for the reconciliation of contemporary concepts of sovereignty with the existence of antecedent aboriginal societies.

The honour of the Crown is also to "be understood generously in order to reflect the underlying realities from which it stems." Acting honourably gives rise, the Court continued, to different duties in different circumstances. The presence of a settled claim frequently gives rise to a fiduciary duty, binding the Crown to act in the best interests of the particular Aboriginal society. The certainty provided by an agreement or treaty enables the Crown to discem what, specifically, are those best interests. Chief Justice McLachlin found the Haida's claim to the Queen Charlottes, though historically sound, lacked "defined or proven" title, and therefore was absent the sufficient specificity for a fiduciary-type duty to arise. However, the honour of the Crown is an element of treaty negotiation and settlement. While the process is ongoing, the honour may require the Crown to consult and, where possible, accommodate Aboriginal interests.

Various attorneys-general intervened at both the Court of Appeal and Supreme Court levels. Together, they argued with the Crown that a general duty to consult - ranging from mere notification for Aboriginal societies with the most speculative or historically questionable claims, to accommodating those groups with recognized claims of minimal dispute, to a fiduciary obligation for peoples who have achieved a settlement (a spectrum developed by the Court of Appeal and approved by the Supreme Court) - was impractical and imprecise. The appropriate level of consultation, they argued, was impossible to determine given the complex facts of each settlement claim and negotiation. It was also suggested that consulting with claimants before a final determination amounts to giving a remedy before issues of infringement and justification are decided.

The Court wholeheartedly rejected these arguments. Quoting the key cases of Delgamuukw v. British Columbia and $R$. v. Sparrow, ${ }^{8}$ the Court held that a duty to consult arises when the Crown has real or constructive knowledge of an Aboriginal society's right or possible claim. Reconciliation, McLachlin C.J.C. continued, is not a legal remedy in the strict sense, but part of a process that is constitutionally protected. ${ }^{9}$ Practically, McLachlin C.J.C. conceded that some knowledge of the scope and material elements of a claim is necessary before the Crown can consult or accommodate in a meaningful way, but this can be achieved without the necessity of an actual settlement. She added that no obligation is imposed on the Crown to cease resource management in the course of negotiations

b Jid. at para. 17.

[1997] 3 S.C.R. 1010|Delgamuskw].

[1990] I S.C.R. I075.

Constitution Act. 1982. R.S.C. 1985. App. II, No. 44, s. 35. 
altogether, or to reach an agreement as a result of consultation. The spectrum, the Court asserted, is manageable in the sense that accommodation may be necessary if amendments to the Crown's process or proposal are suggested as a result of the consultation process; in other words, consulting leads seamlessly to an understanding as to when accommodating is feasible. Feasibility itself is a factor; the Crown has an obligation, fundamentally, to weigh the competing interests in its proposal against the weight of the Aboriginal group's claim, and to use the result of the consultation process to achieve an outcome consistent with the balancing of those interests. Regulatory schemes, it is noted, can provide further guidance as to how the spectrum could be used most effectively.

The Court of Appeal's reasons for finding that Weyerhaeuser also had a consultative obligation - being that such an obligation would be rooted either in the equitable doctrine of knowing receipt, or the ability of a third party to rely on justification as a defence against infringement - were rejected. The honour of the Crown, from which consultative obligations flow, cannot bind third parties. The language of fiduciary obligations and "trustlike" relationships, the Court found, cannot be responsible for imputing the whole of classical equity into the relationships developed between Aboriginal societies and other parties. In short, the Court found the trust relationship between the Crown and the various peoples was not a trust in the strictest sense, and could not give rise to equitable duties incumbent upon third parties. Particular criticism was reserved for Finch C.J., who observed that third parties, aside from the above-discredited equitable arguments, should be held to their duty in order to provide an effective remedy. Chief Justice McLachlin noted that the "remedy tail cannot wag the liability dog,"10 and clarified that liability must arise before the question of remedies. Although the third party, on these facts, is in the best position to provide the desired result, the provision of said result was found not to be their explicit legal or equitable responsibility.

Lastly, the province of British Columbia attempted to avoid responsibility by arguing the consultative duty was solely on the shoulders of the federal government. They used the constitutional division of powers to justify this submission. Chief Justice McLachlin disagreed, noting that the provinces take their interests in land subject to any Crown interest other than that of the province. The assertion of Crown sovereignty, which pre-dated Confederation but gave rise to the honour concept, is one such interest. This recitation of classic Canadian constitutional principles of organization and federalism is a rare argument from the Supreme Court, but one that is clearly effective in attributing long-standing Crown obligations to its embodiment in the form of the provincial government.

\section{COMMENTARY}

Just as Delgamuukw" was a turning point for Aboriginal groups with settled land claims attempting to achieve a power of consent to the Crown's handling of resources insofar as they were affected, Haida is a key case for groups whose claims are not yet settled or are in the process of negotiation. The decision allowed McLachlin C.J.C. to resurrect her dissent in R. v. Marshall: ${ }^{2}$ The Crown's obligations of accommodation and consultation begin with 
its awareness of Aboriginal claims to title, and increase if the Aboriginal group is the subject of a treaty or a legal settlement. A spectrum of accommodation, in this case used to evaluate the position of Aboriginal groups seeking to be heard on public matters and decisions, is a frequent tool of administrative review.

\section{B. TAKU RIVER TLINGIT FIRST NATION V. BRITISH COLUMBIA (PROJECT ASSESSMENT DIRECTOR) $)^{13}$}

Haida was handed down on the same day as a related matter, Taku River. This case gives an opportunity to evaluate the spectrum of consultation and accommodation as outlined in Haida, and applied by its creators in the person of McLachlin C.J.C.

Redfern, a mining company, was seeking permission from the Government of British Columbia to reopen a mine in the area of the Taku River. The First Nation, who participated in the environmental assessment process under the British Columbia Environmental Assessment $A c t,{ }^{14}$ objected to a proposed road development for the servicing of the mine, which would run through their traditional territory. The Province approved the project in 1998. The First Nation brought a successful application to quash the decision on the grounds that the Province had not sufficiently assured itself that the Aboriginal community's issues were addressed before making the decision. That application was upheld on appeal.

The Supreme Court of Canada applied the "honour of the Crown" formulation in their decision to allow the Province's appeal, stating clearly that the Crown had a duty to consult the Taku River Tlingit whose claim, although not settled, was well-known and relatively uncontroversial. The question was whether the Crown's actions sufficiently discharged that duty, giving the Court an opportunity to place a specific instance on the accommodation spectrum as described in Haida.

The Environmental Assessment Act process was held to fulfill the accommodation duty, as the First Nation was part of the Project Committee, and participated fully from the beginning. Participation in the Committee by all stakeholders was in good faith. The process was a statutory requirement for the development to be approved, and was viewed as a meaningful enterprise that made efforts to accommodate the Taku River Tlingit's concerns, as well as those of other participants. Seeing as the consultation process was of value, the Court was unwilling to import upon the Province the obligation to come to an agreement with which all parties were satisfied; this was viewed as an impossible demand. Given the meaningfulness of the process and the steps taken towards accommodating the First Nation to a certain extent, the Court held that the Province had discharged its duty. 


\section{Administrative LAW}

\section{A. ALLIANCE PIPELINE V. ALBERTA (MINISTER OF MUNICIPAL AFFAIRS) $)^{15}$ \\ 1. FACTS}

Alliance Pipeline (Alliance) constructed a billion-dollar, one-of-a-kind pipeline to carry gas from British Columbia and northwestern Alberta to Chicago. The pipeline was subject to municipal taxation, and an assessment was prepared by the Minister's assessor, under the authority of s. 291 of the Municipal Government Act. ${ }^{16}$ The $M G A$ specifjes that, for linear property (of the type a pipeline would involve), no assessment is to be prepared (and therefore no property tax is to be levied) for a property under construction, unless it is capable of transmitting gas, oil, or electricity. The section is designed to prevent utilities from pushing back "in-service" dates on new infrastructure, even if it is technically functioning, to avoid municipal taxes.

The assessment, in the aggregate, amounted to $\$ 422$ million after the assessor determined the pipeline was "capable of transmitting gas." Alliance appealed that determination to the Municipal Government Board (MGB), which held hearings and upheld the assessment. This case was a judicial review of that decision. The facts, as decided by the MGB, were not in question. The standard of review, and the issue of whether the MGB failed to address the issue that the Alliance pipeline was singled out for unique treatment, formed the core of the review.

\section{DECISION AND ANALYSIS}

The Alberta Court of Appeal, in the 2003 decision of Alberla Energy v. Goodwell Petroleum Corporation Lid., ${ }^{17}$ accepted that four factors were to be considered by a court in its attempt to select a standard of review for administrative tribunals or like decision-making bodies. These factors were established in U.E.S., Local $298 \mathrm{v}$. Bibeault, ${ }^{18}$ and are regularly applied in other provincial jurisdictions. The factors are: (i) the presence or absence of a privative clause or statutory right of appeal; (ii) the expertise of the tribunal relative to that of the reviewing court; (iii) the purposes of the legislation and the statutory provision in question in particular; and (iv) the nature of the question.

The privative clause protecting the MGB is found in s. 506 of the $M G A$, and was understood in Alberta (Minister of Municipal Affairs) v. Telus Commuications ${ }^{19}$ as being relatively weak. The section simply indicates that no appeal exists from MGB decisions, but makes no mention of review. The Telus case also recognized the MGB as an expert tribunal, and the trial judge accepted the view that the purpose of the MGB was, amongst other things, to assess municipal taxes fairly and equitably. The question at issue was one of statutory 
interpretation. In essence, was the determination of the pipeline's operational capability one of fact or law?

Alliance contended that the suitability of the line for the transmittal of gas was a legal question, involving the application of a statute. The factual questions faced by the MGB, Alliance submitted, concerned the real value of the assessment. The definition of "capable" for transmission is a legal one, and would be precedent-setting. For these reasons, Alliance argued the Court had as much competence to decide the issue as the MGB, and pushed for a standard of correctness to be applied. The Minister of Municipal Affairs, on the other hand, believed the determination of capability of the pipeline's use was one of "mixed fact and law," and ought to be accorded a higher level of deference. This would be consistent with the standards for mixed questions established in the landmark decision of Ryan v. Law Society of New Brunswick. ${ }^{20}$ An examination of Alberta (Minister of Municipal Affairs) $v$. Alherra (Mimicipal Governmem Board) $)^{21}$ reveals discussion of the standard of review for mixed fact and law-type determinations, where a decision as to whether software used for switching gear on telecommunications lines is "linear property." The MGB heard expert evidence in deciding that question, with the Court of Appeal deciding that, because "realities of the marketplace" for the software provided a factual context for statutory interpretation, it was a matter of mixed fact and law. Justice Mahoney, in Alliance, agreed with that assessment: to "subject all administrative board decisions involving questions of law to a correctness review, abandoning the functional and pragmatic approach, would be to expand the scope of judicial review considerably beyond what the legislature intended."22 Following the Ryan decision, the question of the pipeline's suitability for the transmission of gas was one of mixed fact and law, as the determination involved the "application of general principles of the Act to specific circumstances." ${ }^{23}$ It was also concluded that the MGB applied itself fairly and equitably to Alliance's submissions before it. The standard of review was held to be patent unreasonableness.

\section{COMMENTARY}

This case gives insight into the application of Ryan, a recently decided matter that altered our understanding of appropriate review standards for questions involving legal interpretation. Traditionally, policy arguments were made in favour of minimal deference to lower courts and tribunals - not out of disrespect or distrust, but to uphold the importance of the law being applied correctly and consistently. Justice Mahoney cited numerous examples, however, of judges happy to accept the role administrative tribunals play in the judicial process, and welcomed the delinition achieved in Ryan of what is a mixed fact/law determination. 


\section{B. MARITIME \& NORTHEAST PIPELINE LLP V. EILIOTT ${ }^{4}$}

\section{FACTS}

Maritime and Northeast Pipeline Limited Partnership (MNP), was granted a certificatc of "public convenience and necessity" for the construction of a pipeline to transport gas from Nova Scotia to markets elsewhere in the Maritimes and New England. The creation of the right-of-way for the pipeline, which was $25 \mathrm{~m}$ wide, was not opposed by the Minister of Natural Resources (the Minister) or the Elliotts in particular, who were landowners near the pipeline's pathway. The right-of-way did not physically contact or overlap with the Elliott's property, although a small portion of their land was within the $30-\mathrm{m}$ controlled area established under s. 112 of the National Energy Board $A c r^{25}$ (the $A c t$ ). MNP did not acquire a right of way from the Elliotts for access to their property.

The Elliotts, seeking compensation for inconvenience and an alleged diminution of value of their property as a result of the pipeline development (or, more specifically, the 30-m restricted zone), availed themselves of a statutory arbitration scheme and filed their notice of arbitration, notifying the Minister and MNP in due course. The Minister responded with requests for submissions. By correspondence dated 9 August 2002, the Minister advised the parties that no arbitration committee would be appointed regarding compensation in relation to the controlled area, but such a committee would be appointed instead to examine lost value of their property due to proximity to the pipeline. The Minister had not asked for submissions on this subject.

Two issues arose from this decision as petitioned by MNP: firstly, did the Minister err in determining that the arbitration procedure established in Part V of the $A c t$ applied to the Elliott's claim at all; and secondly, did the Minister fail to observe a principle of natural justice in failing to provide MNP an opportunity to be heard on the issue of whether the Minister had jurisdiction to appoint the arbitration committee?

The standard of review, as clarified in Balisky v. Canada (M.N.R. $)^{26}$ was one of correctness. The Elliotts vigorously argued that the decision to call an arbitration was one to be reviewed using an unreasonableness yardstick, but long-respected principles of Canadian administrative law reserve such a test for determinations of law or mixed law and fact.

MNP argued that the facts of Balisky, involving a similar situation, applied strictly to the controlled area and land where the pipeline company had taken an interest. They argued that, in such a circumstance where the legal imposition on the landowners or occupiers was clear, arbitration committees may be appropriate. If Balisky was widely applied to anyone who deemed themselves affected by the pipeline, MNP would face indeterminate liability. The Elliotts argued the Minister ought to have taken a "contextual" approach to interpreting the statute, submitting principles from Dell Holdings Lid. v. Toromo Arca Transil Operating 
Authority. ${ }^{27}$ This case stated, generally, that ambiguity in the nature of rights in an expropriation should be resolved in favour of the landowner, and that a presumption exists whereby, when property rights are taken from a citizen, compensation follows. The Minister, joined as a defendant and, relying on the Interpretation $A c t,{ }^{28}$ argued that every act "shall be deemed remedial and shall be given such fair, large and liberal construction and interpretation as best ensures the attainment of its objects. ${ }^{, 29}$ The purpose, they continued, behind Part $\mathrm{V}$ of the $\mathrm{Act}$ is to provide an efficient and just mechanism for the determination of adequate compensation where damages arise due to the exercise by pipeline companies of their rights under the $A c t$. Given the benefits of swift procedure and flexibility inherent in the arbitration scheme, it was rational to conclude it was intended to be used not just to hear claims related to lands taken or otherwise encumbered by the pipeline company, but also lands that may be otherwise affected by the construction or operation of a pipeline.

\section{DECISION AND ANALYSIS}

Justice Layden-Stevenson, hearing the case in Federal Court, precisely stated the thrust of the case. She noted that, at its core, this dispute related to whether or not the $A c t$ provides for compensation for injurious affection and, if it does, whether it distinguishes between situations where land is taken and where it is not. Since the Minister has a statutory duty not to refer matters to arbitration that are not within his or her jurisdiction, this is a determination the Minister himself or herself ought to have made, and ought to have made correctly. Thus, the standard of review consistent with determinations of law, correctness, is properly employed in this circumstance.

After a brief consideration of standard rules of interpretation governing divergences between the French and English text of a federal statute, and the presumption that words used repeatedly in a piece of legislation will carry the same meaning, the Court determined that the definition of "lands" in the "Definitions" section of the $A c{ }^{30}$ did not apply to s. 90 (the section empowering the creation of an arbitration committee). The Court concluded that this could not be consistent with the object of the $A c t$. Part $\mathrm{V}$ was clearly for the purpose argued by the Minister: achieving efficient and just compensation. The Court did hold, however, that s. 84 of the $A c t$, enabling damages to be paid, did not relate to injurious affection and therefore no compensation could be granted. The Elliotts were not entitled to arbitration and the Minister's decision was consequently quashed.

\section{Alberta Energy v. Goodwell Petroleum Corp. Ltd."}

\section{BACKGROUND}

The gas-caps at the center of the "Gas over Bitumen" issue also pose difficulty for splittitle arrangements, i.e., the separation of oil sands and natural gas rights in the same land area and "geological horizon." When a gas-cap is present, the current technologies used in the 
recovery of bitumen require the production of some initial gas-cap gas. Oil sands lessees cannot produce the bitumen they are entitled to recover unless they have a right to produce some initial gas-cap gas. Despite this inevitable truth, the Alberta Energy and Utilities Board (AEUB) took the position that a Crown oil sands lessee has no right to produce any initial gas-cap gas incidental to bitumen recovery. The natural gas lessee's consent is required. If no agreement can be reached, the bitumen well may be shut-in. Such an occurrence forms the basis of the appeal in this case.

\section{FACTS}

Goodwell Petroleum Ltd. (Goodwell) held the petroleum and natural gas leases on certain sections in the Athabasca oil sands area of Goodwell, Alberta. Alberta Energy Company (AEC) acquired the bitumen rights, and concluded operations that included certain SAG-D operations with a total investment of over $\$ 20$ million. Goodwell did not drill any gas wells. Goodwell argued that bitumen production from the 16 drilled SAG-D wells were producing exceptionally high quantities of initial gas-cap gas. Talks ensued between Goodwell and AEC, and when they failed, Goodwell proceeded to sue AEC in the Court of Queen's Bench. The suit is ongoing. Goodwell also applied to the AEUB to shut-in the 16 wells. In a 2000 decision, the AEUB agreed to shut-in four wells, which were producing the largest gas to oil ratio. This decision was predicated on two reasons: first, the AEUB believed the production of gas would endanger Goodwell's ability to later exploit its own production rights; and second, in its opinion, AEC had no licence or right to produce gas from the wells. AEC had argued that "it was entitled to produce that quantity of gas-cap gas required to exploit its bitumen resource without consideration for the gas mineral lease owner," ${ }^{32}$ provided it used good production practices and accepted industry extraction techniques.

The AEUB rejected this argument, adhering to a strict interpretation of AEC's lease. They stated in their decision that "AEC East's interests in this pool include only bitumen and solution gas.... Accordingly, AEC East must obtain all of the rights to produce overlying gas through some form of agreement or revenue-sharing formula." ${ }^{33}$ The production of initial gas-cap gas, the AEUB maintained, would be a violation of AEC's lease.

AEC applied for leave to appeal, which was granted on the questions: i) whether the AEUB erred in jurisdiction or law in determining that AEC's right to produce leased substances under its oil sands leases did not include the production of initial gas-cap gas; and ii) whether the AEUB erred in shutting-in the wells until such time as AEC has "the full rights to produce" the gas (i.e., a licence) and by encouraging it to enter into a cost-sharing agreement.

In March 2002, AEC asked the AEUB to review and vary the 2000 decision. In the previous two years, AEC had satisfied all the conservation requirements mandated by the AEUB in relation to their first reason for shutting-in the wells. Goodwell had allowed all but one of its leases to expire. The Alberta Government had, by this time, imposed a moratorium on public and private offering of petroleum and natural gas rights in the area. This was 
commensurate with the then-ongoing public hearings into the shutting-in of numerous productive gas wells so as to preserve access to bitumen. The AEUB denied AEC's request, noting the second reason for shutting-in the wells persisted. The appeal of that decision was granted on two issues: first, whether the AEUB erred in law and jurisdiction in determining that AEC's right to produce leased substances under its oil sands leases does not include any production of initial gas-cap gas; and second, whether the AEUB erred in determining that, in the circumstances of this case, production of natural gas by AEC, other than associated solution gas, will result in a contravention of AEC's licences and of the Oil and Gas Conservation Act. ${ }^{34}$

The appeals of both decisions were heard together. Goodwell took no position on the issues and made no submissions.

\section{DECISION AND ANALYSIS}

Applying the four-part test set out in Bibeaull, ${ }^{35}$ Fruman J.A. for the Alberta Court of Appeal decided the appropriate standard of review for each of these questions was that of correctness. The application of this test revealed a minimal degree of deference was owed to the AEUB's findings.

The issue of "split-title," or the resolution of conflicts centered around the separation of petroleum and natural gas rights, was first addressed authoritatively in the case of Borys $v$. C.P.R. and Imperial Oil LId ${ }^{36}$ Two important clarifications emerged from that decision: one, natural gas lessees were entitled to the gas-cap gas and petroleum lessees were entitled to solution gas; and two, the extent to which petroleum rights holders could use initial gas-cap gas to extract petroleum. The Court of Appeal stated that "the reservation of the petroleum in the grant of the land enables [the petroleum rights holders] to use all reasonable means to extract the petroleum from the carth.... [T] he [rights holders] are entitled to extract all the petroleum from the earth, even if there is interference with and a wastage of [Borys'] gas, so long as in the operations modern methods are ... reasonably used and the provisions of the relevant statute and regulations are observed." ${ }^{.37}$ Borys was revisited and reaffirmed in the landmark decision of Anderson v. Amoco Canada Oil and Gas. ${ }^{38}$

The AEUB submitted that the Borys principles can be distinguished in three ways: scientifically, as the bitumen extraction problem differs from that encountered with relation to petroleum gas-caps; contractually, as the terms of the specific oil sands leases and related instruments override Borys; and by statute, as the Alberta oil sands statutory regime abrogates the Borys principles.

[1951] 4 D.L.R. 427 (Alta. S.C. (T.D.)), rev'd in part, [1952] 3 D.L.R. 218 (Alta. S.C. (A.D.)), aff d, [1953] 2 D.L.R. 65 (P.C.) [Borys]. 
Justice Fruman responded to the Board's scientific argument with evidence, notably the 1998 Report "Gas/Bitumen Production in Oil Sands Areas," "39 which suggested the AEUB's investigations had established that the "production framework currently in place for conventional oil recovery could be adopted for primary bitumen recovery." that the scientific differences between each process were previously regarded as being minimal. An analysis of the decisions following Borys indicate that key common law principles in interpreting rights under mineral leases apply to all instruments that convey mineral rights. From the extensive case law on the subject, the Court of Appeal discerned several key principles:

1. A right to mines and minerals includes the right to work, dig, and use all reasonable means to recover the minerals, and,

2. If recovering the minerals results in a known and inevitable consequence, a court cannot enjoin mining and recovery of the minerals.

3. These principles apply to Crown leases equally as to other leases.

4. While a bare right to a mineral conveys a right to win, work, and carry away the mineral, that power can be expanded or restricted by express wording in the deed.

\title{
5. Relevant statutes may modify these principles.
}

The Court of Appeal, analyzing these general principles, stated that:

\begin{abstract}
Applying these principles to the present case, a bare right to oil sands would include the right to use all reasonable means to recover the bitumen in the oil sands. As the discussion of scientific principles indicated. if a gas-cap exists, production of some initial gas-cap gas is an inevitable and expected consequence of bitumen recovery. Initial gas-cap gas production would therefore be an implied term. The fact that oil sands rights were granted by a crown lease rather than a reservation does not affect this conclusion, unless the words of the lease or related documents limit the right to produce initial gas-cap gas."
\end{abstract}

An analysis of AEC's leases revealed to the Court of Appeal that no restriction or impediment to initial gas-cap gas production was incorporated in any of those documents. Considering the statutory regime, Fruman J.A. noted that Borys was heard at a time when Alberta had a sophisticated regulatory regime emphasizing conservation. The AEUB argued that 5.54 of the Mines and Minerals Acr' ${ }^{22}$ states that "no person shall win, work, or recover a mineral that is the property of the Crown in right of Alberta unless the person is authorized to do so under this Act or by an agreement." This appears to be a departure from Borys, where it was concluded that if each party had a right to access the minerals or hydrocarbons, no agreement between them was needed. The Court, however, in reviewing the definition of "agreement" in s. I of that $A c t$, found that the agreement in s. 54 refers to the lease itself, i.e., 
the agreement with the Crown or the landowner. The Court continued with a comparison of the regulatory and statutory regime upon which the AEUB sought to rely and that were in existence in 1951, and found the two to be, materially, the same. The Court concluded, therefore, that the Alberta energy statutes do not restrict the application of the Borys principles.

In conclusion, an examination of science, Borys and the case law that followed it, and the statutory regimes in both 1951 and contemporaneously, support AEC's claim that their express right to win, work, and recover bitumen under its leases entitled them to produce initial gas-cap gas incidental to bitumen recovery, subject only to the rights Goodwell may have for compensation. The four grounds of review were each answered in the affirmative, and the appeal was allowed.

\section{ASSET PURChases}

\section{A. WELLTEC APS V. PRECISION DRILLING CORP. ${ }^{43}$ \\ 1. BACKGROUND}

It is a well-established general rule that a purchaser of assets will not be liable for contractual obligations entered into by the seller with a third party unless the purchaser has been expressly novated into the contract. There are a number of exceptions to this general rule but, as this case illustrates, the exceptions are of limited application.

\section{FACTS}

The plaintiff, Welltec APS (Welltec), developed a unique device used to develop and service oil wells, known as a well tractor. In April 1995, Welltec sold two well tractors to a German company called Preussag Wasser. The sale contract included provisions whereby Welltec retained the ownership of the intellectual property rights and patents for the well tractors. The contract expressly prohibited Preussag Wasser from manufacturing products identical or similar to the Welltec well tractors. Welltec did not hold a patent on the tractors in Canada.

In 1999 Preussag Wasser sold certain assets, including the two Welltec well tractors, to a joint venture established between the defendant, Precision Drilling, which carried on business internationally as Computalog, and a German company. The joint venture was called Computalog Europe GmbH.

Welltec sued Precision Drilling alleging that it improperly copied the design of the Welltec well tractors in manufacturing its own well tractors. Among other things, Welltec alleged that the defendants breached the express and implied terms of the April 1995 contract entered between Welltec and Preussag Wasser. 
Precision Drilling brought an application for summary dismissal of the Welltec claims for breach of contract. Precision Drilling argued that none of the defendant companies were parties to the contract of April 1995 between Wellec and Preussag Wasser. Precision Drilling argued that when the Computalog Europe joint venture was created, the assets, and not the shares of Preussag Wasser, were acquired and no contractual obligations of Preussag Wasser were assumed.

In response, Welltec argued that although contractual obligations cannot normally be transferred without a novation agreement, in certain circumstances if a third party has express or implied notice of the contract, the contract can be enforced against that party. Welltec relied on the so-called "De Mattos principle." where a purchaser acquires property with knowledge of a previous contract with a third party to use the property for a particular purpose, the purchaser cannot use the property in a manner not permitted by the contract.

Welltec also argued that the contractual covenant not to copy the well tractor design was similar to a covenant in restraint of trade. Although there was no express novation of the contract in this case, Welltec argued that the circumstances of the case fit into one of the two exceptions to the general rule that the burdens of a contract are not assignable, as set out in Silver Butle Resources Lid. v. Esso Resources Canada Lid.:

\footnotetext{
The first [exception] is the conditional benefit and burden principle that where an assignee takes the benelit of a contract and that benefit is conditioned directly upon the performance of some obligation. the assignee must, as a matter of law, accept the burden also... The secend principle is ... the pure benefit and burden principle that even though a benefit may be independent of a burden, the cireumstances under which the assignee came to obtain the benefit may result at law in his being saddld wilh the burden."
}

\section{DECISION}

The defendants' application for summary dismissal was granted. The defendant companies were not parties to the contract relied upon by the plaintiff. The $D e$ Mostos principle did not apply. The principle is an equitable one and was only intended to allow a court to grant an injunction to restrain the third party from doing something inconsistent with the performance of the original contract; ${ }^{\text {th }}$ that is, to restrain a purchaser from using the property in a manner contrary to the permitted uses of the property under a previous contract. The DeMattoss principle did not "provide a panacea for outllanking the doctrine of privity of contract." could not impose contractual obligations where none existed.

The court also rejected Welltec's argument that the circumstances of the case fell within exceptions to the general rule against the assignment of the burdens of a contract without a novation agreement. 


\section{COMMENTARY}

This case reinforces the notion that the principle of privity of contract will ordinarily preclude a third party from suing a purchaser of assets under a contract (between the seller and the third party) relating to the assets, unless the purchaser has been novated into the contract. The case serves as a reminder that in circumstances such as a joint venture situation, where the original parties to a contract relating to assets desire to ensure that a purchaser of the assets is bound by the contract, care must be taken to ensure that the contract contains appropriate provisions that will prohibit the assets from being sold unless the purchaser agrees to be novated into the contract in the place of the seller.

\section{BUILDERS' LIENS}

\section{A. TJ INSPECTION SERVICES V. HALIFAX SHIPYARDS ${ }^{48}$}

\section{BACKGROUND}

Until recent amendments were enacted under the Nova Scotia Mechanics ' $\mathrm{Lien} A \mathrm{Al},{ }^{49}$ the MLA had a unique feature that allowed a mechanics' lien (commonly known as a builder's lien or construction lien in other jurisdictions) to be claimed against ships or vessels. This case considered whether a component of a fixed offshore gas production platform, while under construction onshore, could be subjected to a mechanics' lien under the $M L A$.

\section{FACTS}

Halifax Shipyards was retained to construct the topside for an offshore natural gas production platform for the South Venture field as part of Tier II of the Sable Offshore Energy Project. The topside is a structure designed to ultimately rest on top of four legs on the ocean floor. The topside was being constructed on lands leased by Halifax Shipyards in Dartmouth, Nova Scotia. During the construction process, Halifax Shipyards retained TJ Inspection Services (TJ) to provide inspection services. A dispute arose between the parties and $\mathrm{TJ}$ asserted it had not been fully paid according to the terms of the contract. TJ filed a claim of lien under the $M L A$ in respect of its outstanding accounts. Hatifax Shipyards applied for an order vacating the lien on the basis that a lien could not be validly asserted against the topside structure under the MLA.

The issue was whether a lien can be validly claimed under the $M L A$ against a topside for a fixed offshore production platform while it is under construction onshore.

\section{DECISION}

A lien could not be validly claimed under the $A c t$ against the topside structure. The lien claim (and $l i s$ pendens) was ordered vacated. 
Under s. 6 of the $M L A$, a lien can be claimed against an "erection," "ship," or "vessel" among other types of property. The relevant portions of s. 6 read:

6(1) ... any person who performs any ... service ... in respect of ... the making ... of any erection, ... ship [or] ... vessel ... or the appurtenances to any of them. for any owner, contractor, or subcontractor, shall by virtue thereof have a lien for the price of such ... service ... upon the erection ... ship [or] ... vessel ... and appurtenances, and the land cecupied thereby ... or in respect of which such ... scrvice is performed. ${ }^{51}$

In this case, TJ claimed a lien on the topside structure itself as opposed to the land. The property to be charged by the lien was described as the "South Venture Topside's Structure," being an "erection" or "vessel" forming part of a larger offshore platform, to be constructed for the Tier 2 fields of the Sable Offshore Project presently located at a common area wharf in Halifax.

The topside would weigh approximately 2300 tonnes upon completion and rest on four legs connected to the seafloor when emplaced. The topside would be taken to the site by barge and assembled in place by a heavy-lift crane. Once the topside has been emplaced on the production platform, neither it nor the platform was intended to move or float, and did not have means of propulsion nor the ability to navigate.

The first question was whether the topside structure could be considered an "erection." Since the topside was not bolted or otherwise affixed to the ground, but was merely resting on the ground during construction until moved to the offshore platform site where it would be permanently installed, the structure did not constitute an "erection" as contemplated in s. $6(1)$ of the $M L A$. The Court held that the topside was nothing more than a large chattel resting upon, but in no way attached to, the land where it was being assembled.

The Court also considered whether the topside structure could be considered a "vessel" or "ship." The Canada Shipping $A c^{5 \prime}$ defines a "ship" as any description of vessel used in navigation and defines "vessel" as including "any ship or boat or any other description of vessel used or designed to be used in navigation." $"$ The Federal Courts Act defines "ship" as follows:

2(1) "Ship" means any vessel or craft designed, used or capable of being used solely or parlly for navigation, without regard to method or lack of propulsion, and includes

(a) a ship in the process of construction from the time that it is capable of floating, and

(b) a ship that has been stranded, wrecked or sunk and any part of a ship that has broken up. 53 
The Court determined that in order for the topside structure to be considered a "ship" or "vessel" it must at least be capable of floating. The topside structure did not meet this test. It was never designed to float. It was not a vessel or ship. Nor could the topside be considered as an appurtenance of a "ship" or "vessel" since there was nothing to suggest that the platform (to which the topside would become part), once completed, would ever float. The Court held that the topside was not a vessel or a ship, and no lien could be claimed against it under s. 6 of the MLA.

\section{COMMENTARY}

Subsequent to the decision in this case, the $M L A$ was amended to eliminate the concept that a mechanics' lien could be claimed against ships and vessels. The case does, however, stand as authority for the principle that the components of a major structure, like an offshore production platform, while under construction or fabrication on-shore, cannot be the subject of a mechanics' lien in Nova Scotia. A structure of this type, or a component of it, while temporarily on land during fabrication, is not an erection or structure being constructed so as to be permanently affixed to the land where it is located during the fabrication phase.

\section{B. DELOITTE \& TOUCHE V. MERIT ENERGY LTD. ${ }^{54}$}

\section{BACKGROUND}

Suppliers of goods and services to a well site may be able to recover the unpaid purchase price of the goods or services supplied by filing a construction or builder's lien against the leasehold interests of the operalor or joint owners of the project. In circumstances where the owner of the well site operates multiple well sites, the question can arise as to whether the supplier can claim a "general" lien on all of the properties, or is confined to claiming a lien in respect of the specific site to which the goods or services were supplied.

\section{FACTS}

Merit Energy Limited (Merit) held varying interests in a number of petroleum and natural gas leases granted by the Crown in Saskatchewan. In most cases, the interests held by Merit in the Crown leases were less than 100 percent. Merit contracted with a number of different companies for the supply of services and equipment to various sites operated under the leases.

Merit experienced financial difficulties which led to its receivership and, ultimately, its bankruptcy. Deloitte \& Touche (Deloitte) was the receiver/manager and trustee in the bankruptcy of Merit.

Merit failed to pay the accounts of its suppliers. Four of them registered builder's liens, pursuant to the Builders' Lien Acts of Saskatchewan, against the interests of Merit in the various petroleum and natural gas leases. 
In its capacily as receiver, Deloitte sold the property of Merit and applied for and obtained an order from Hunter J. of the Saskatchewan Court of Queen's Bench confirming that title to the property passed to the purchaser free and clear of all encumbrances, including the builder's liens. The order specifically provided that the net proceeds of the sale would stand in the place of the property being sold.

The funds received from the sale of the property were insufficient to pay all of the lien claimants and unsecured creditors of Merit. The receiver applied to the Court for directions specifically relating to the validity of the builder's liens.

It was conceded that the four lien claimants were creditors of Merit in the amounts claimed. However, the trustee in bankruptcy questioned the validity of the liens because they were asserted as "general" liens against all of the interests of Merit in the various Crown leases, and not on an individualized basis in respect of the specific properties on which work was performed.

The general liens purported to constitute a claim against each property on which it was registered, for the full value of all outstanding amounts and for all work done on all of the properties.

The Chambers Judge found that the lien claimants did not hold valid liens. The Chambers Judge was of the view that the appropriate test to determine whether a general lien is valid is whether a single contract existed for improvements on more than one property owned by the owner. The single contract need not necessarily be a formal written contract. It can consist of several documents. One single contract must, however, be clearly identified. In this case, there was no evidence submitted by any of the lien claimants of a single contract containing all of the essential elements of a contract. Therefore, the Chambers Judge was of the view that the failure by the lien claimants to establish the existence of a single contract meant that the contractors did not have a general lien. This was not merely a matter of a failure to comply with form, but rather a substantive failure to qualify the entitlement to a general lien.

After the Chamber Judge's decision regarding the validity of the general lien claims, the lien claimants asked the Chambers Judge to consider their status as "individual lien claimants." 36 The Chambers Judge held that, in accordance with the provisions of the order of Justice Hunter, since the claimants had not filed valid proofs of claim for individual lien claims, their lien claims "shall be deemed to be extinguished without further order." consequence, the lien claimants were held not to have priority over unsecured creditors of Merit. The lien claimants appealed. 


\section{DECISION}

The Saskatchewan Court of Appeal allowed the appeal. The lien claimants were entitled to priority over unsecured creditors notwithstanding their failure to validly register the claims for liens.

Under the $B L A$, a lien claimant has a lien against the interest of the owner in the property in respect of which work is performed as soon as it first provides service or materials. In this case, the lien claimants did not lose their status as lien holders under the $A c r$ despite failing to "perfect" their liens by proper registration and the Order of Hunter J., which extinguished the liens if they did not file proper proofs of claim. The Court of Appeal held it was a mistake to draw an analogy between the registration of liens under the $B L A$ and secured transaction concepts such as "perfection" under the Personal Property Security Act, 1993. ${ }^{58}$ In matters involving the determination of the effect of the failure to register a claim of lien on the validity of the lien, it is the $B L A$ that governs.

Under s. 49(1) of the $B L A$, a lien expires unless a claim of lien is registered within the 40day period provided in s. $49(2)$. However, s. $49(1)$ is subject to s. $49(5)$. Under s. $49(5)$, it is possible to register an "expired" lien late, and it will be regarded as validly registered against that portion of the unpaid contract price. This is the case except as against the claim of an intervening party who has an actual estate or interest in the land or the claim of a payor who has made a payment without notice of the lien.

The priority between a lien claimant and an unsecured creditor depends on when the lien arises, not registration. Section 70(1) of the $B L A$ accords priority to unregistered liens over unsecured creditors. The Court of Appeal was of the view that a rule conferring priority on lien claimants over unsecured creditors is consistent with the underlying theory of builders' lien legislation, which recognizes the unique position of those who provide services and materials without security but, nonetheless, improve real property.

The failure of the lien claimants to register valid claims of lien, did not deprive them of the status of unregistered lien claimants. If the lack of valid registration was the only issue to be determined, the lien claimants would take priority over the unsecured creditors.

\section{COMMENTARY}

This case is a reminder that in order for a supplier of goods and services to claim a valid general construction lien against multiple properties, there must be a single contract for the supply of the goods or services containing all of the essential elements of an agreement. In Saskatchewan, at least, the failure of a lien claimant, who has filed a general lien, to prove entitlement to a general lien under a single contract may not be fatal. Such a lien claimant may still have priority over other creditors, as an unregistered lien claimant, by registering an "expired" lien against the individual properties. These registered expired liens will have priority so long as there have been no intervening events giving rise to rights of third parties. 


\section{CONFIDENTIAL INFORMATION}

\section{A. HUSKY OLL OPERATIONS LTD. V. ANADARKO CANADA CORP.}

\section{BACKGROUND}

Confidentiality agreements typically contain an exception allowing a party to disclose confidential information when it is required to do so by law. In this case, a recipient of confidential information was not required by law to disclose information. but it sought permission from the court to do so in order to prove a claim it was asserting in litigation.

\section{FACTS}

Husky Oil Ltd. (Husky) and Gibson Petroleum Company Limited (Gibson) were competitors in the business of transporting crude oil for producers. one of which was Anadarko Canada Corp. (Anadarko). In 1996 and 2000, Anadarko entered into agreements with Husky, which contained confidential tariff and pricing information as well as confidentiality clauses that prohibited the parties from divulging the terms of the agreements without the express written consent of the other party.

In 1997 and 1999, Anadarko and Gibson entered into agreements for the transportation and blending of Anadarko's heavy oil. Disputes arose between the parties resulting in Anadarko commencing an action against Gibson. Anadarko alleged that Gibson had overcharged for condensate, supplied butane but charged Anadarko for condensate, and added too much condensate to Anadarko's heavy oil. Anadarko also claimed that Gibson had misrepresented that Anadarko would receive better net backs than it was receiving at that time pursuant to its agreements with Husky. Anadarko intended to prove that allegation by reference to its agreements with Husky. Husky, however, refused to consent to disclosure of this confidential information.

Anadarko applied for an order permitting it to produce the documents, subject to a confidentiality order to protect Husky's interests. Husky brought a cross-application for a declaration and an injunction enjoining disclosure of the information by Anadarko. Husky consented to disclosure of some of the confidential information, but objected to the disclosure of tariff and pricing information. Husky argued that it would suffer irreparable harm if Gibson acquired its tariff and pricing information. According to Husky, that information would allow Gibson to adjust its bids to undercut Husky's prices.

The Chambers Judge concluded that the information in question was not privileged and must be produced, subject to certain confidentiality restrictions. In particular, the Chambers Judge ordered that disclosure be restricted to Gibson's counsel, expert witnesses, and other Gibson employees who were directly connected with the case and who would be required to review the documents for the purposes of the litigation. Husky appealed. 


\section{DECISION}

Granting production of documents and granting a confidentiality order both require the exercise of judicial discretion. The standard of review for decisions involving judicial discretion has a high threshold. An appellate court should not interfere with the exercise of judicial discretion merely because the court might conclude that the discretion should be exercised differently. An appellant must demonstrate that there has been an error in principle, misapprehension of facts, or the exercise of discretion in a non-judicial manner.

Confidential information must ordinarily be produced if it is relevant to the action, notwithstanding a confidentiality agreement. There are cases, however, in which a qualified privilege may exist such that a party will not be required, or permitted, to disclose the confidential information. The following four criteria (the Wigmore criteria) will determine whether such a privilege exists:

(1) The communications must originate in a conlidence that they will not be disclosed.

(2) This element of confidentiality must be essential to the full and satisfactory maintenance of the relation between the parties.

(3) The relation must be one which in the opinion of the community ought to be sedulously fostered.

(4) The injury that would inure to the relation by the disclosure of the communications must be greater than the benefit thereby gained for the correct disposal of litigation. ${ }^{60}$

The Alberta Court of Appeal found that the Chambers Judge made no reference to the four Wigmore criteria, nor did he individually examine documents to decide whether a privilege arose on a case-by-case analysis. As a result, the Court of Appeal set aside the Chambers Judge's decision and remitted the matter back to the Court of Queen's Bench for a determination of privilege on a case-by-case basis with respect to each of the documents for which privilege was claimed.

\section{COMMENTARY}

This case is interesting because it involved a situation where a party to a confidentiality agreement sought permission of the court to be excused from its confidentiality obligations under the agreement for the purposes of producing documents relevant to a claim that it was asserting in litigation. Interestingly, the Court seemed to have no difficulty finding it had authority to permit the disclosure of the documents in the litigation notwithstanding the existence of a confidentiality agreement, which presumably did not itself permit the disclosure of the documents in these circumstances. 


\section{Contracts}

\section{A. PURE ENERGY MARKETING LTD. V. RAMARRO RESOURCES ${ }^{\text {ol }}$}

\section{BACKGROUND}

Courts are generally loath to impose implied terms into contracts freely negotiated between two parties, especially where the contracting parties are sophisticated business people. The Courts will imply a term into a contract where necessary for business efficacy in order to ensure that the commercial purpose of the contract can be fulfilled. While it is fairly rare for a court to intervene by implying into a contract a term or condition that the parties themselves did not turn their minds to, there are cases where a court perceives that the demands of justice require a contractual term to be implied to prevent an unjust or unfair result. This is one of those cases.

\section{FACTS}

Pure Energy Marketing Ltd. (Pure) was a marketer of natural gas. KCS Energy Management Services (KCS) contacted Pure to secure a long-term supply of natural gas. Pure then approached Ramarro Resources (Ramarro), a supplier of natural gas, to supply gas to KCS. A letter agreement was signed by the three parties in 1989, in which Ramarro and KCS acknowledged Pure as the agent who brought them together and in which Ramarro agreed to pay Pure a fee of CDNS0.04 per gigajoule of gas delivered under the contract.

Ramarro and KCS entered into a long-term 15-year gas sales contract in July 1989. In 1994, Ramarro and KCS entered into an amended and restated gas contract that allowed the contract to be terminated on six months notice if a purchase price for the gas to be supplied under the contract could not be negotiated. At about the same time, Ramarro and Pure entered into two forms of commission agreements, both of which contained an agreement by Ramarro to pay Pure the CDN\$0.04 per gigajoule fee.

On 26 April 1995, KCS gave notice to Ramarro of its intention to terminate the gas sale contract at the end of October 1995. Negotiations between the two parties resulted in KCS agreeing to pay US\$850,000 to Ramarro as an accord and satisfaction for the early termination of the gas sale contract. Nomination and delivery of natural gas from Ramarro to KCS ended on 30 April 1995. Ramarro paid Pure the fees for all gas nominated and delivered under the gas sale contract up to 30 April 1995. No commissions were paid to Pure after that. Ramarro asserted that the fees were to be paid only for gas "nominated and delivered"62 to KCS, and no gas was sold to KCS after 30 April. 


\section{DECISION}

Pure's action against Ramarro for damages for the commissions it was not paid as a result of the early termination of the gas sale contract was successful. The Alberta Court of Queen's Bench held that a term should be implied in the agreement between Pure and Ramarro to the effect that Ramarro could not enter an agreement allowing KCS to terminate the gas sale contract early in exchange for a substantial carly termination payment to Ramarro without incurring liability to Pure for the commissions Pure would have earned had the gas sale contract continued for the term specified in the contract. An appeal by Ramarro to the Alberta Court of Appeal was dismissed. Ramarro then sought leave to appeal to the Supreme Court of Canada, which dismissed the application for leave without reasons on 8 January 2004.

\section{COMMENTARY}

All three levels of court that looked at this case came to the same conclusion: it would be unfair for the gas supplier to receive a very substantial payment from the gas buyer in exchange for the supplier's agreement to terminate the gas supply contract early, without any recognition of the avoided cost to the gas supplier of commissions payable to the marketing agent. Because there was an agency agreement which governed the relationship between the gas supplier and marketing agent, the Court could not resort to concepts of unjust enrichment to redress the situation. The Court decided instead to impose an implied term into the contract. While it is debatable whether the term implied by the Court in this case was strictly necessary in order to give efficacy to the agency agreement, the faimess of the result is more difficult to argue against.

\section{B. C.D. OIL WELL SERVICING LTD. V. PRAIRIE WELL SERVICING LTD. ${ }^{63}$}

\section{BACKGROUND}

Occasionally a case arises that serves as a reminder of "first" principles. One of the first principles of contract law is that a contract, even a complex one in writing, must be supported by consideration to be enforceable. This case considered the validity and enforceability of a "workout" arrangement between a well operator and an unpaid well services contractor. The arrangement involved a number of complex written agreements intended to facilitate the development of certain wells to generate cash flow to pay off the well operator's debts, including liabilities to the service contractor.

\section{FACTS}

C.D. Oil Wells Servicing Lid. (C.D. Oil) supplied materials and services to Prairie Well Drilling Ltd. (Prairie Well) in connection with the operation of two of Prairie Well's oil well sites. When its accounts for the materials and services were not paid, C.D. Oil commenced an action and subsequently entered default judgment. In accordance with a writ of seizure issued pursuant to the judgment, the Sheriff seized two vehicles belonging to Prairie Well. 
Prairie Well then applied for an Order for the return of the vehicles, arguing that C.D. Oil's claim had been settled pursuant to the workout agreements.

\section{DECISION}

Prairie Well's motion to set aside the seizure of the vehicles was dismissed. The Court held that there was no consideration flowing from Prairie Well to C.D. Oil under the workout agreements. The agreements did contain a process whereby C.D. Oil would be paid, but it was conditional upon the wells producing and generating cash flow. There appeared to be no firm definitive promise by Prairie Well under the agreements to pay C.D. Oil. As a consequence, there was not an enforceable contract and C.D. Oil's ability to seize the vehicles to satisfy its judgment was not affected.

\section{COMMENTARY}

As this case illustrates, basic contract law principles require that a contract, even a complex written agreement, must be supported by consideration to be enforceable. Consideration is typically found in the form of some identifiable covenant or promise: without it, the agreement may not be enforceable.

\section{ViI. Corporations}

\section{A. PEOPLES DEPARTMENT STORES (TRUSTEE OF) V. WISE ${ }^{\text {b4 }}$ \\ 1. BACKGROUND}

Issues relating to the extent of directors' personal liability to creditors of a corporation are of obvious interest to all directors and their legal advisors. Some very significant issues of that type came before the Supreme Court of Canada in Peoples Department Stores Inc. (Trustee of) $v$. Wise.

\section{FACTS}

In an environment of intense competition in the Canadian retail industry in the early 1990's, Wise Stores (Wise) acquired Peoples Department Stores (Peoples) as a whollyowned subsidiary. Wise's founder had three sons who were officers and directors of Wise. After the acquisition, those three sons also became the only directors of Peoples.

The Wise family employed a new business strategy to avoid duplication of the respective business systems of $W$ ise and Peoples stores. They also employed a joint inventory system and a new procurement policy to coordinate the wholesale purchases for the stores. Peoples purchased from North American suppliers and Wise purchased from overseas suppliers. Each branch was to invoice the other accordingly for transferred inventory. 
Neither business succeeded. By June 1994, Wise owed approximately $\$ 18$ million to Peoples. It was agreed that the new procurement policy would be rescinded by 31 January 1995. The brothers claimed that the new policy could not be terminated earlier.

Both Wise and Peoples were petitioned into bankruptcy, and both were declared bankrupt as of 9 December 1994. The realization of the assets covered the secured debts of both Wise and Peoples, but the claims of trade creditors remained outstanding.

The trustee in bankruptcy for Peoples then filed a petition against the Wise brothers alleging that, as directors of Peoples, they had favoured the interests of Wise over Peoples, resulting in a detriment to the creditors of Peoples. It was alleged that the directors had breached their duties as directors of Peoples under s. 122(1) of the Canada Business Corporations $A$ Att $^{65}$ Further, the trustee claimed that the brothers had been privy to "reviewable transactions," as contemplated by s. 100 of the Bankruptcy and Insolvency Act, ${ }^{\text {t6 }}$ in connection with the transfer of inventory from Peoples to Wise.

The trial judge held that the directors' duty of care under s. 122(1) of the $C B C A$ extended to creditors of a company if the company is "in the vicinity of insolvent" insolvent. The procurement policy was held to be a breach of these duties, and the brothers were found liable for $\$ 4.4$ million in damages. The directors' were also found liable on the basis of being privy to reviewable transactions contrary to the $B I A$. The directors' insurer, Chubb, was also found liable.

The Quebec Court of Appeal overturned the trial judge's determinations with respect to both the liability of the directors, and the insurer. The Court of Appeal held the trial judge was incorrect in finding a breach of the duty of care by the directors under the $C B C A$ and, in particular, in deciding that the best interests of the creditors necessarily coincided with those of the corporation (to which the duty is owed) merely because a company may be on the brink of insolvency.

The Court of Appeal also overturned the finding of liability under the reviewable transaction provisions of the $B I A$. In that regard, the trial judge, having determined that approximately 94 percent of fair market value had been obtained by Peoples for the inventory that had been transferred to Wise, it was an error for the trial judge to hold that this constituted an amount "conspicuously" less than fair market value within the scope of s. $100(2)$ of the $B I A$.

\section{DECISION}

The Supreme Court of Canada affirmed the reasoning of the Quebec Court of Appeal, and dismissed the appeal against the Wise brothers and their insurer, Chubb. 
Noting that the provisions of the Civil Code of Quebec ${ }^{68}$ serve as a supplementary source of interpreting the meaning of the provisions in the $C B C A$, the Court parsed the duties of directors as follows:

Section 122(1)(a) provides that directors must "act honestly and in good faith with a view to the best interests of the corporation." The Court characterized this first branch of the section as a "statutory fiduciary duty." ""

Section $122(1)(b)$ requires that directors "exercise the care, diligence and skill that a reasonably prudent person would exercise in comparable circumstances." The Court labeled this as the "duty of care" owed by directors to the corporation. ${ }^{30}$

The Court held that the two duties are separate, and that the trial judge confused their distinct operation. With respect to the statutory fiduciary duty, the trial judge held as a fact that there was no fraud or dishonesty on the part of the Wise brothers. The Court of Appeal held their sole desire was to rectify the historical problem of inventory procurement. In confirming the Court of Appeal's conclusion, the Supreme Court stated:

\begin{abstract}
As explained above, there is no doubt that both Pcoples and Wise were struggling with a serious inventory management problem. The Wise brothers considered the problem and implemenled a policy they hoped would solve it. In the absence of evidence of a personal interest or improper purpose in the new policy. and in light of the evidence of a desire to make both Wise and Peoples "better" corporations, we find that the directors did not breach their fiduciary duty under s. $122(1)(a)$ of the CBCA. See 820099 Ontario Inc. v. HaroldE. Bullard Lid. (1991), 3 B.L.R. (2d) 123 (Ont. Gen. Div.) (alf d (1991), 3 B.L.R. (2d) 113 (Ont. Div. C1.)), in which Farley J., at p. 171, correctly observes that in resolving a contliet between majority and minority shareholders, it is safe for directors and oflicers (1) act to make the corporation a "better corporation." 71
\end{abstract}

The Supreme Court noted that creditors are also afforded protection under s. 24l(2)(c) of the $C B C A$ through the oppression remedy. Where a company finds itself at the brink of insolvency, there is an increased likelihood that a creditor will be successful in convincing a court that it can be classified as a "complainant" and, therefore, a "proper person" under s. 238(d) of the $C B C A$ to bring an oppression action or derivative action. Given the availability of these alternative remedies for creditors, the Supreme Court concluded that creditors were not owed a statutory fiduciary duty by the directors under s. 122(1)(a) of the $C B C A$.

The Supreme Court found that the duty under s. 122(1)(b) should manifest a deference to business decisions of management of the corporation. In this case, the Court was of the view that the decision to implement the new procurement policy was a reasonable business decision, and the trial judge's finding that it was this decision that led to Peoples' ultimate bankruptcy was a palpable and overriding crror. 
The Supreme Court then considered the "reviewable transaction" claim under s. 100 of the BIA. The Supreme Court noted that two components must be present in order to establish a reviewable transaction under the $B I A$ : (1) the transaction must have occurred within one year of the date of bankruptcy; and (2) the consideration given or received by the bankrupt must be "conspicuously greater or less" than the fair market value of the relevant property. The trustee in bankruptcy had not succeeded in establishing a reviewable transaction in this case. The Court stated:

We are not salisfied that, with regard to all the circumstances of this case, a disparity of slightly more than six pereent between fair market value and the consideration received constitutes a "conspicuous" difference within the meaning of s. 100 (2) of the BIA. Accordingly, we hold that the trustee's claim under the BIA also fails. ${ }^{2}$

\section{COMMENTARY}

The Supreme Court of Canada was firmly of the view that there was no statutory fiduciary duty owed by the directors to creditors under s. 122(1)(a) of the $C B C A$. While the interests of creditors and other stakeholders may be relevant in determining the best interests of the corporation, the mere fact that a company is on the brink of bankruptcy does not trigger a mandatory consideration of creditors' interests by directors.

Reviewable transactions under the $B I A$ require that the amount received by the bankrupt for its property be "conspicuously" less than its fair market value. The amount realized for the bankrupt's property in this case was 94 percent of fair market value, and the trial judge's characterization of this sum as "conspicuous" was held to be a "palpable and overriding error." ${ }^{.73}$

Although the protections for creditors under both the $C B C A$ and the $B I A$ are extensive, directors will be given considerable deference under the "business judgment rule" when making decisions affecting the financial health and, potentially, the financial life of the corporation.

VIII. Damages

\section{A. amoco Canada Petroleum v. Propak Ststems Lto. ${ }^{74}$ \\ 1. BACKGROUND}

Difficulties in assessing damages can arise in cases where, as a result of the wrongful conduct of one party, another party is forced to defer production of its oil or gas reserves for a period of time, but the overall volume of the reserves is not impacted. 


\section{FACTS}

The plaintiffs held natural gas interests in the Drayton Valley area, and processed their gas through the Eta Lake gas processing facility. In 1989, the plaintiff, Union Pacific, hired the defendant, Propak Systems Limited (Propak), to construct a skid in connection with a refurbishment of the Eta Lake facility. The construction of the skid took place at the Propak manufacturing facility, and was subsequently transported to the Eta Lake site in January 1990.

On 1 November 1990, the skid, as well as the building housing it, was destroyed by fire. A subsequent investigation revealed that a motor shaft had broken and flown off, affecting a small valve which allowed propane to escape and ignite the fire. As a result of the fire, the plant was shut down for repairs for a three month period. Propak was found to be responsible for the fire.

The plaintiffs' total volume of gas reserves were not affected by the fire. The claim by the plaintiffs related to the fact that production of the gas was delayed to a later time as a result of the plaintiffs being unable to process gas at the facility until repairs were made.

\section{DECISION}

The damages for the plaintiffs' claim for business interruption losses were calculated by taking the expected level of production that would have been achieved from the wells feeding into the plant, and deducting the level actually produced during the loss period. The result of this calculation was then adjusted by a credit for the value of the deferred production. The procedure accepted by the Court to value the deferred production began by ascribing value to the reserve pools from which the wells could have drawn production. Second, for each pool, the year in which the deferred production would take place was determined. This involved determining the expected life of the pool and assuming the deferred production would occur in the final year of production. Third, future cash flows from the deferred production were derived from the determined values for prices, royalties. and operating costs applicable to the reserves. Finally, the future cash flow was discounted, using common industry rates, to derive net present values.

\section{COMMENTARY}

This case demonstrates the level of complexity involved in determining the value of deferred production for the purposes of calculating a damages claim. The approach adopted by the Court in this case may serve as a useful formula for making these calculations in future cases and in other contexts. The essential role of experts in the process is also illustrated. The factual assumptions made by the various experts were analyzed by the Court in deciding which expert view to accept. The decision of the Court in this regard was based on a conclusion that the preferred evidence was "well prepared, meticulous and objective."7s The case illustrates the judicial tendency to prefer evidence that is objective and well- 
balanced, and conversely the risk of rejection of experts who take an advocacy-like approach in their analysis. ${ }^{76}$

\section{B. MONTREAL TRUST V. WILLISTON WILDCATTERS CORP. ${ }^{\text {" }}$}

\section{FACTS}

The appellant, Montreal Trust, was the registered owner (as bare trustee) of the mineral rights to a certain piece of land in Saskatchewan. The appellant was not itself authorized to produce oil or gas, according to the trust agreement. The appellant granted a petroleum and natural gas lease to a lessee, which provided for Montreal Trust to receive a gross overriding royalty of 12.5 percent. In 1989, TDL Petroleums (TDL), a respondent in this action, acquired the leasehold interest by assignment and took over operation of a producing well (the 12-8 well). The primary term of the lease had expired and the lease was "held by production" pursuant to its own terms. Production from the well ceased between January and July 1990. In that year, TDL entered into a farmout agreement with Williston Wildcatters Corp. (Williston), in which TDL warranted the validity of their lease. Williston subsequently assigned most of its interest in the farmout to several of the respondents. Some of those working interests were further assigned.

In May 1991, the 12-8 well was shut-in, but not abandoned. A new well was drilled on the subsection (the 11-8 well). In the Saskatchewan Court of Appeal's recitation of the facts, how much the appellant knew about the new well is disputed. In any event, in 1992 the appellant wrote to Williston, requesting information on drilling activity and suggesting the lease had terminated for want of production. The appellant later suggested a new lease with a gross overriding royalty of 18 percent. This was rejected and a new lease was not negotiated.

In February 1993, Montreal Trust began this action. The trial was divided into two stages: first, adjudication on the status of the original lease and, second, adjudication of damages.

\section{DECISION AT TRIAL}

The trial judge found that the lease expired in January 1990 due to non-production. At the end of the first trial, the parties entered into a consent order (Williston having been replaced by other entities following its bankruptcy in 1995) in which the respondent, Long Riders Rig Corporation, agreed to continue producing from the $11-8$ well, with the proceeds paid into court. The trial judge found the respondents were trespassers from the point of nonproduction until the consent order had been agreed.

It was held that the respondents had converted the oil produced from the appellant's wells, and that damages would be the same for trespass or conversion. The trial judge considered whether the plaintiff/appellant, Montreal Trust, ought to be granted the value of what was produced with or without an allowance for the cost of production. Citing Shewish v. 
MacMillan Bloedel, ${ }^{78}$ the trial judge decided some deduction for the costs of production ought to be allowed, but also found as a fact that Montreal Trust could not have produced the leased substances itself or retained a unitholder to do so. The most the plaintiff/appellant could have reaped from the substances being produced was a royalty. Damages were assessed on the basis of the best royalty the appellant could have received, with respect to the production of each well (both the 11-8 and the 12-8).

\section{DECISION ON APPEAL}

Whether or not the appellant had consented, by leave and licence, to the respondents' operation of the wells was a point of litigation. It was argued that Montreal Trust had tolerated the respondents' presence and ought not to use the Court to suspend leave indefinitely. The trial judge found that no consent or leave had been given to the respondents by the appellant. The Court of Appeal, led by Vancise J.A., held otherwise. The Court of Appeal broke down the timeframe, finding a licence was implicilly granted to the respondents after the appellant's 1992 letter, and before the lawsuit was launched; i.e., during the period of re-negotiation of the royalty agreement. The Court of Appeal distinguished the case law cited by counsel and the trial judge by noting that, in this instance, a previous lease existed. The "grey area" of authority surrounding the termination of that lease - itself not so clear cut as to be decided without resort to litigation - could be more easily characterized as leave and licence by the appellant than it could trespass by the respondent.

This finding affected the way damages were assessed. The appellant contended that the trial judge erred in assessing damages on a compensatory rather than restitutionary basis. The appellant sought full compensation for the value of its minerals, minus a figure for production costs. The Court of Appeal indicated its support for the idea that damages should be assessed so as to put the plaintiff/appellant, Montreal Trust, in the position it would have been in had the trespass or conversion not occurred. The Court of Appeal, in noting the coexistence of "hard" (no production costs allowed) and "soft" (production costs considered) rules, interpreted authority to suggest that the application of specific damages provisions, so as to restore the plaintiff's position on the whole, were malleable to the particular facts of the case. The trial judge had contended that the nexus of the dispute was mutual mistake as to the meaning of the lease agreement. The Court of Appeal agreed, noting also that the paying of damages in the traditional sense, being the valuc of production either with or without production costs, could amount to a windfall for Montreal Trust, which was never in a position to receive the total market value of the oil produced from either well. 


\section{EASEMENTS}

\section{A. WESTSIDE LAND CORP. V. DESZYNSKI ${ }^{79}$ \\ 1. BACKGROUND}

In order to be valid and enforceable, an easement must meet a number of established criteria. One of these is that the easement must not take away all of the proprietary and possessory rights of the servient tenement owner so as to amount to a grant of title in fee simple. This case shows how far an easement can restrict the rights of the servient tenement owner without violating this requirement.

\section{FACTS}

Deszynski purchased a property in 1984 from an estate. In order to access the land, Deszynski purchased an easement over an adjacent parcel of land from the same estate. The easement was purchased for significant consideration, and was registered on title on 14 September 1984. The easement allowed Deszynski to build an access road and covered a large area of land because it was not known at the time where the access road would be built. In 2002 Westside Land Corp. (Westside) purchased the servient property that was subject to the easement.

In this proceeding, Westside applied for a declaration limiting the scope of the easement only to the roadway which had been built on the property.

The following criteria must be met for an easement to be valid:

(i) there must be a dominant and a servient tenement;

(ii) the easement must accommodate the dominant tenement;

(iii) the dominant and servient owners must be different persons; ...

(iv) the easement must be capable of lorming the subject matter of a grant ...

(v) [the right cannot be] too wide or vague;

(vi) [the grant must be consistent] with the proprictorship or possession of the alleged servient owner; and

(vii) [it must not be] a mere right of recrealion without utility or benefit. ${ }^{80}$

Westside argued that unless the easement was interpreted so as to restrict it to the location where the roadway was actually built, it would offend the requirement that the easement must not be inconsistent with the owner's proprietorship or possession of the servient tenement.

\section{DECISION}

The first issue was whether the Court could rely on extrinsic evidence to determine the intention of the parties when the easement was created. Extrinsic evidence is not admissible when the wording of an easement is clear and unambiguous. The easement involved in this 
case was clear and unambiguous and, therefore, the Court refused to consider extrinsic evidence, stating that the result of accepting Westside's position would be to "alter substantially the ordinary meaning of the words used in the easement."

The Court held that the easement, as written, applied to the entire area of land and was not specific to the roadway. The construction of a roadway was the primary purpose of the easement but the grant also included other incidental purposes including landscaping and fencing, which obviously would not occur directly on the roadway. If the parties had intended that the easement apply only to the actual roadway, the easement could have been drafted to reflect that intention.

The Court rejected Westside's argument that the easement was unenforceable given its inconsistency with the possessory and proprietary rights of the owner of the servient tenement so as to amount, in essence, to a transfer of title in fee simple to the easement holder. In rejecting this argument, the Court stated that "while an easement cannot equate with a transfer of land, the rights contained can significantly detract from the owner of the servient tenement's rights and still be held enforceable." 82

A grant of easement which purports to deprive the owner of the servient tenement of all proprietary rights and the right of possession may be invalid. In this case, the grant of easement did not grant "exclusive use" of the servient tenement to the easement holder. It only granted "exclusive rights," meaning that the fee simple owner could not grant those rights to any other party. The fact that the easement holder could use the land, build a roadway and fences and landscape it, and that the owner was prohibited from building on the land, did not amount to exclusive and unrestricted use by the easement holder.

While the easement restricted the use to which the owner of the servient property could put the land, it did not amount to a grant of title to the easement holder and, although it restricted the servient owner's rights, it did not deprive the owner of all of its proprietary rights. The easement met the requirements for a valid easement.

The Court declined to consider how the land subject to the easement might be used by the current owner. However, the Court did offer that the casement holder did not have the right to exclusive use of the land, that the servient property owner could subdivide the land and that no one could build on the land except for the easement holder who was permitted to build a road and a fence.

\section{COMMENTARY}

An easement may be held to be invalid if it purports to deprive the servient property owner of all proprietary and possessory rights to the land. It is clear from this case, however, that short of granting "exclusive use" of the property to the easement holder, the fact that the rights of the fee simple owner to build on the land are severely restricted is not enough to invalidate a grant of easement. 


\section{Evidence}

\section{A. MOSAID TECHNOLOGIES V. SAMSUNG ELECTRONICS ${ }^{83}$ \\ 1. BACKGROUND}

Every litigant is under a duty to ensure the preservation of all documents in its possession that may be relevant in litigating the dispute. As electronic and digital record-keeping becomes increasingly prevalent, issues relating to the preservation and production of electronic and digital data are becoming more common.

\section{FACTS}

Ottawa-based MOSAID Technologies (MOSAID) sued Samsung Electronics (Samsung) in a New Jersey court with respect to patent infringement. After commencement of the litigation the defendant, Samsung, did not take adequate steps to preserve and protect its digital records concerning matters relevant to the claim advanced. In addition, Samsung did not adequately take protective measures once certain orders were made for production of documents.

Samsung failed to place a "litigation hold" on a document retention policy related to its email system. The technology automatically deleted emails after a certain time. Earlier proceedings in this matter determined that Samsung failed to produce a single technical email related to the patent litigation.

MOSAID sought sanctions against Samsung, and the Court held that Samsung's reason for failing to preserve the emails was inadequate. MOSAID was granted its request for a spoliation inference. Samsung appealed this decision, and argued that spoliation was an extreme sanction and that permitting an adverse inference (that the destroyed information would have supported the patent infringement application) was an error of law.

\section{DECISION}

At issue before the United States District Court of New Jersey was the validity of two of the sanctions imposed against Samsung: the spoliation inference jury instruction regarding the destroyed emails, and the monetary sanctions in the form of attomeys' fees and costs for MOSAID's motion for sanctions and attempts to obtain discovery.

Justice Martini cited case law defining spoliation as "the destruction or significant alteration of evidence, or the failure to preserve property for another's use as evidence in pending or reasonably foreseeable litigation." ${ }^{4}$ The Court noted that the available sanctions for spoliation include dismissal of the claim, suppression of evidence, an adverse inference, fines, or attorneys' fees and costs. It was determined that the spoliation inference in instructions to a jury is a far less drastic form of sanction compared to the dismissal or 
suppression of evidence. The Court established that four essential factors must be met in order for a spoliation inference to be made:

First, "it is essential that the evidence be within the party's control." .. Second, "it must appear that there has been actual suppression or withholding of the evidence." ... Third, the evidence destroyed or witheld was relevant to claims or delenses. ... And fourth, it was reasonably foresetable that the evidence would later be discoverable. 85

\section{The Court cited Scort:}

While a litigant is under no duty to kecp or retain every document in its possession, even in advance of litigation it is under a duty to preserve what it knows, or reasonably should know, will likely be requested in reasonably foreseeable litigation. ${ }^{86}$

Justice Martini found that Samsung had clear control of the emails and that it was reasonably foreseeable they would be sought in subsequent discovery. He held that the duty to preserve exists as of the time the party knows or reasonably should have known that litigation is foreseeable. The Court found it completely unacceptable that, given service of the claim in September 2001, Samsung took no steps in the intervening three-year period to change the automatic delete function of its email systems.

Samsung argued that the "actual suppression" component of the test requires that there was intention indicative of fraud and a desire to suppress the truth, and that spoliation "does not arise where the destruction was a matter of routine with no fraudulent intent." ${ }^{87}$ The Court held that the suppression need not be actual, rather it must only appear to be actual. There is no requirement of bad faith to support a spoliation inference order.

The Court held that the spoliation inference is a lesser sanction and is more appropriate given its remedial function. It cited two secondary rationales for the sanction: punishment and deterrence. It noted that these must play a secondary role. Samsung was aware that it had a duty and was also aware that it had information which would be relevant to foreseeable litigation. It was aware of how to change its email processes and did not do so. Samsung exhibited wilful blindness by not preventing the destruction of the emails on a rolling basis.

\section{COMMENTARY}

In its conclusion, the Court summarized the significance of this case, noting that automated email systems cannot be used as a shield against the litigation obligation to preserve evidence in the control of a party. Given the increased role played by electronic documents in litigation, it is incumbent upon parties to ensure that systems are properly maintained to allow for production of relevant documents. 
Litigation counsel need to be mindful of this obligation and take early steps to ensure that the client takes adequate steps to preserve all digital records. The extent of this obligation is not currently defined, but may also include an obligation to preserve computer hard drives that contain deleted digital records that are relevant to matters in issue. General counsel will also need to take steps to develop systems to maintain and preserve evidence, and to ensure that externally retained litigation counsel are given sufficient authority to meet this objective.

\section{INJUNCTIONS}

\section{A. ANDROSCOGGEN ENERGY LLC V. PRODUCERS MARKETING LTD. ${ }^{\mathrm{kx}}$ \\ 1. BACKGROUND}

This case considered whether an order in the nature of a mandatory interim injunction should be granted requiring a seller of natural gas under a fixed price contract to continue to deliver gas where replacement gas was available on the spot market, pending arbitration of a contract dispute between the buyer and seller.

\section{FACTS}

Androscoggen Energy entered into a long term contract to buy 11,000 gigajoules per day of gas at pre-determined prices from Producers Marketing Ltd. (Pro-Mark). Until 1 September 2003, Pro-Mark supplied the full amount of gas under the contract. Following this date, Pro-Mark reduced its deliveries to 2000 gigajoules per day and claimed force majeure on the basis that the Alberta Energy and Utilities Board had issued an order to shut-in a large number of gas wells in portions of Alberta. This failure to deliver the contract volumes forced Androscoggen to buy replacement gas on the spot market at prices more than twice the contract price $-\$ 30,000$ per day. The resulting dispute was referred to arbitration.

In the meantime, Androscoggen applied for an interim order for specific performance compelling Pro-Mark to provide 11,000 gigajoules of gas per day, pursuant to their contract, pending the outcome of the arbitration process.

\section{DECISION}

The application was granted. Pro-Mark was ordered to supply the contract quantity of gas pending completion of the arbitration.

An interruption of one source of gas did not relieve the seller from the obligation to obtain natural gas from other sources, and sell and deliver it to the buyer. Under the contract, the burden of proving the occurrence of an event of force majeure was on the seller. Until the seller succeeded in proving this in the arbitration, the seller was obligated to continue to perform the contract. Morcover, even if the seller was successful in proving an event of force majeure, it was still required under the terms of the contract to take all reasonable steps to 
continue performance of the contract. If the buyer was able to buy replacement cover gas on the spot market to make up the deficiencies in supply, then so too could the seller.

In determining whether or not the applicant was entitled to an injunction ordering specific performance of the contract, the Court analyzed the well-known tri-partite test established in $R J R$-MacDonald v. Canada (A.G. $)^{89}$ involving a consideration of: (i) whether there was a serious issue to be tried; (ii) irreparable harm; and (iii) the balance of convenience.

In the present case, the Court determined that there was a serious issue to be tried. Insofar as irreparable harm was concerned, the Court recognized that the fact the claim was "entirely monetary" would normally be fatal to a claim of irreparable harm. But, in this case, some of the monetary damages claimed by Androscoggen were not compensable under the gas purchase and sale contract. Under the contract, for instance. Androscoggen could not claim interest or other costs of obtaining replacement gas, and was not entitled to consequential damages. Moreover, the Court was of the view that the fact that Androscoggen was forced to make a cash outlay, which should have been a burden on Pro-Mark, constituted irreparable harm.

Finally, the Court's view was that the balance of convenience favoured granting the injunction:

\begin{abstract}
However, there are three reasons that the balance of justice favours an order for specific performance of the contract. The respondent is contractually obligated to provide gas to the applicant and the applicant is entitled to rely on the supply contract. A court of justice cannot ignore a breach of contract. If the arbitrator ultimately decides that there is not an event of Force Majeure, the respondent is obligated to do all things necessary to assure the delivery of gas, and if the arbitrator decides that there is an event of Force Majeure, the respondent must "exercise all reasonable efforts" to continue to perform its obligation under the agreement and to remedy expeditiously its inability to do so. To not grant an injunction would result in relieving the respondent of its contractual obligations. ${ }^{90}$
\end{abstract}

The Court ordered that, pending the completion of the arbitration, Pro-Mark had to do all things necessary to assure the supply of 11,000 gigajoules per day of natural gas as required under the contract with Androscoggen.

\title{
4. COMMENTARY
}

This case is interesting in part because of the Court's approach to the general rule in an interim injunction application; that the test for irreparable harm will not be met where damages can be monetarily compensated. In this case, the Court held that, under the gas purchase contract, if the seller failed to deliver the contract quantity of gas, the buyer would not be entitled to recover damages for interest or other costs of obtaining replacement gas or consequential damages. This was sufficient, in the Court's view, to satisfy the test of irreparable harm and justify the granting of an injunction requiring the seller to perform its contractual obligations pending the outcome of the arbitration. In doing so, the Court 
recognized a potentially significant interim remedy for oil and gas buyers whose deliveries are curtailed by the seller in a market of raising prices.

\section{B. Dastous V. CANADIAN NATURAL. RESOURCES LTD." \\ I. BACKGROUND}

Although courts are more likely to grant injunctions in nuisance cases, interim injunction applicants continue to bear the burden of satisfying the test of irreparable harm and balance of convenience. In this case, a couple living near the Canadian Natural Resources Ltd. oil sands project in Alberta attempted to halt the development of the project, and sought an injunction which, had it been granted, would have resulted in losses of $\$ 3$ million per week to the developer and the delay of a project capable of producing 232,000 barrels per day of synthetic crude oil.

\section{FACTS}

The plaintiffs, Claude and Maureen Dastous, owned a residence on land leased from the Crown in Alberta. The defendant, Canadian Natural Resources Lid. (Canadian Natural), was involved in the development of an extensive oil sands project in the vicinity. The plaintiffs filed a statement of claim seeking an injunction and damages against Canadian Natural. The plaintiffs claimed that the oil sands project caused, or would cause, a nuisance adversely affecting the plaintiff's trapping and out fitting business, the enjoyment of their residence, and the health of Mrs. Dastous. The plaintiffs applied for an interim injunction pending the trial of the action or settlement of their claim for compensation.

\section{DECISION}

The application for an injunction was dismissed. Justice Johnstone applied the tripartite test for interim injunctions adopted by the Supreme Court of Canada in RJR-MacDonald: ${ }^{92}$

1. Is there an arguable issue to be tried?

2. Has the plaintiff demonstrated that it would suffer a substantial risk of imeparable harm in the period leading up to the trial of the issue:?

3. What party does the balance of convenience favour?"3

The Court stated that the tripartite test was applicable in this case even though the plaintiffs' claim was in nuisance, although Johnstone J. acknowledged that the courts may be more amenable to issue injunctions in nuisance cases.

The Court determined that the issue of the amount of compensation due to the plaintiffs for harm suffered as a result of the proposed oil sands project constituted a serious issue to be tried. 
The Court reviewed whether irreparable harm would occur as a result of the oil sands project in the form of wildlife or environmental damage, loss of business revenue and disturbance, or potential health concerns. No scientific evidence was put forward with respect to environmental or wildlife damage, but the Court took judicial notice that the oil sands project could have such an impact. The Court concluded, however, that any damage to the plaintiffs for loss of business revenue or disturbance could be compensated in damages. Although the plaintiffs raised health concerns, no evidence of harmful effects to health or indication of symptoms was presented. The Court's view was that a mere allegation of health concerns was insufficient for the purposes of establishing a foundation for the granting of an injunction: "Proof of irreparable harm cannot be inferred and must be clear and not speculative. ${ }^{n 4}$

As to the balance of convenience, the consequences of granting the injunction included losses of up to $\$ 3$ million per week for the defendant. The plaintiffs had no ability to compensate the defendant for losses of that magnitude if the plaintiffs' claim was ultimately unsuccessful.

The plaintiffs did not meet the tripartite test for injunction because they did not establish a substantial risk of irreparable harm, and because the balance of convenience favoured the defendant.

\section{COMMENTARY}

The test for granting injunctive relief outlined in RJR-MacDonald ${ }^{45}$ is equally applicable to claims in nuisance. An application for injunction grounded in irreparable harm to either health or the environment requires concrete evidence of such potential. In this case, the significance of shutting down a major project, at a cost to the developer of $\$ 3$ million per week, was not lost on the Court in its assessment of the balance of convenience.

\section{RELENTLESS ENERGY CORP. V. DAVIS}

\section{BACKGROUND}

The existence of Aboriginal and treaty rights can have an impact in a variety of contexts, including applications for injunctive relief. In this case, the Blueberry River Indian Band (the Band) erected a hunting and fishing camp in the path of a proposed access road required for an authorized drilling program. Relentless Energy Corp. (Relentless) sought an injunction and other relief to prevent interference by the Band with construction of the road.

\section{FACTS}

Relentless obtained permits from the British Columbia Oil \& Gas Commission (the Commission) that allowed it to construct a $15-\mathrm{m}$ wide road on Crown land. The Band held 
a trap line registered under the Wildlife $A c t^{97}$ and had trapping rights pursuant to Treaty No. $8^{98}$ that covered the area of the proposed road. The Band filed a request with the Oil \& Gas Commission to review the road construction permit and conduct a land use study assessment. The Band believed that the road construction permit should not be allowed to impede their use of the trap line, which was permitted pursuant to both the Wildlife Act and their constitutional treaty rights, and sought to have the Commission change the location of the proposed road. A decision from the Commission was pending.

In the meantime, members of the Band set up a hunting and trapping campsite at the location where construction of the road was to begin. Relentless sought an interim injunction against the members of the Band to restrain them from obstructing, interrupting, or interfering with the construction of the road.

\section{DECISION}

The Court declined to grant an injunction. The usual threshold question for the granting of an interlocutory injunction is whether the plaintiff's claim raises a serious question that is not frivolous or vexatious ( $R J R-$ MacDonald). ${ }^{99}$ In this case, however, the Band submitted that if the injunction was granted and the road was built, the right of the members of the Band to maintain their hunting and trapping campsite would be effectively rendered moot, and the entire case would be effectively disposed of at the interlocutory injunction stage without a detailed examination of the respective competing rights of the parties. The Court agreed. The Court's view was that if the injunction was granted, Relentless would have no interest in pursuing the claim to trial. The Court's view was that Relentless sought the injunction "as a means to an end, not as a means of preserving anything pending trial."100 Relentless did not plead trespass or nuisance in its claim since it had no interest in the land. Relentless appeared to have no interest in having an adjudication of the competing claims on the merits. In these circumstances, the proper threshold test for granting an interlocutory injunction was whether the plaintiff had shown a strong arguable case on the merits rather than the usual serious question test.

Relentless had not shown a strong case on the merits. Its claim was predicated on "wrongful" interference on the part of the defendants. This required that there be an obstruction, interruption, or interference with property rights. The problem for Relentless was that the road construction permit that it held did not constitute a property right. Moreover, the construction permit, properly interpreted, was not intended to deprive any person of his or her existing rights. Further, the defendant members of the Band were not simply protesters alleging unspecific Aboriginal rights. They were beneficiaries under Treaty 8 and holders of pre-existing, validly-issued trap lines. Finally, the construction permit was issued to Relentless without meaningful consultation with the Band, as required by Halfway River

R.S.B.C. 1996, c. 488.

Canada, Treaty No. 8Made June 21, 1899 and Adhesions, Reports, Sisc. (Onawa: Quecen 's Printer, 1966) [Treaty 8]. See online version of the Treaty at Indian and Nonhern Affuirs Canada, online: <www.aineinac.gc.ca/pr/tris/try8_e.html>.

Supra note 89.

Supra note 96 at para 11. 
Nation v. British Columbia (Ministry of Forests). ${ }^{101}$ For all of these reasons, it could not be said that Relentless had a strong prima facie case on the merits.

Even if the test to be applied in this instance was the minimum threshold of a "serious question," the injunction should not be granted because the balance of convenience favoured maintaining the status quo. Both parties had the potential to suffer irreparable harm based on the outcome of the application. The irreparable harm to the energy company was economic in being delayed in its winter drilling program. The irreparable harm to the defendants would be to deny them the opportunity to engage in meaninglul consultation and accommodation of their treaty rights. When the only effect of the injunction is to postpone the date when a person can engage on a particular course of action, "it is a counsel of prudence to preserve the status quo."102 The status quo was best preserved by denying the injunction in this case.

\section{COMMENTARY}

An interlocutory injunction will not be granted where the balance of convenience does not favour the applicant and both parties will suffer irreparable harm. Additionally, the plaintiff in this case was denied an interlocutory injunction because the Court held it had no interest in pursuing its claim at trial following an order for injunctive relief. Given that the defendants were members of an Indian band, there are special considerations related to consultation which must be respected.

This case illustrates the unique factors at play when aboriginal and treaty rights are considered in the context of the common law test for injunctive relief. Of particular significance is the Court's suggestion that the loss by the Band of its opportunity for consultation and accommodation would constitute irreparable harm.

\section{Joint VENTURES}

\section{A. AWAD V. DOVER INVESTMENTS LTD. ${ }^{103}$}

\section{BACKGROUND}

Typically the rights of a minority interest holder in an oil and gas joint venture are determined by the terms of the joint operating agreement or other contracts relating to the project. Often these rights are fairly restricted. In this case, a minority interest holder in an oil and gas joint venture sought to invoke the oppression remedies under the Ontario Business Corporations $A c t^{104}$ to redress a breach of an oil and gas joint venture agreement. 


\section{FACTS}

Ghareeb Awad (Awad) and Dover Investments Ltd. or a related company (Dover), were parties to two joint venture agreements relating to a number of producing oil fields in Egypt. The joint ventures were controlled by Dover. Awad was a minority interest holder in the joint ventures.

One of the joint ventures was profitable. The other was not. In order to pay ongoing expenses of the second joint venture, cash calls were made on the joint venture participants. Dover withheld from $A$ wad his share of the distribution of profits from the first joint venture to pay his cash call obligations relating to the second joint venture.

Awad brought an application for oppression under the $O B C A$ on the basis that his position in the joint venture was analogous to that of a minority shareholder. Awad also claimed he was a creditor with respect to the joint venture by virtue of the fact that distributions of profits from the joint venture had not been paid to him as required under the joint venture agreement. Awad alleged that Dover acted oppressively by withholding amounts from the distribution of joint venture profits for financing costs, by incurring operating expenses for which it failed to properly account, and by withholding amounts from Awad as set-offs against claims that were unrelated to the joint venture. It was also alleged that Dover made significant decisions with respect to the operation of the oil field without the agreement of Awad.

\section{DECISION}

Section $248(2)$ of the $O B C A$ gives the court authority to grant an oppression remedy where, in respect of a corporation (in this case, Dover), conduct has occurred that is "oppressive or unfairly prejudicial to ... the interests of "... a creditor." A court will treat a person as a "complainant" where the "person is a creditor and the court considers that person to be a proper person to make the application." 105

In this case, Awad claimed that he was a creditor of Dover because Dover had made payments to itself out of joint venture oil revenues that were not permitted under the joint venture agreement. Awad could not say what amount was owing to him, however, because the disclosure by Dover was, according to Awad, inadequate and an accounting was therefore necessary.

In order to be a creditor for the purposes of the oppression remedies under the $O B C A$, the $O B C A$ requires that the person must be a creditor at the time of the alleged oppressive conduct. For a creditor relationship to exist, there must be a debt owing for money or money's worth. The Ontario Supreme Court was of the view that a participant in a joint venture, like Awad in this case, would not, merely by becoming a joint venture participant, be regarded as a creditor for the purposes of the oppression remedies under the $O B C A$. $A$ joint venture participant can be regarded as a creditor only if and when "a distribution of 
profit has become due and payable to him and then only to the extent of the amount so payable and only until the amount is paid."106

In this case, Awad could not be regarded as a creditor unless and until a distribution of profit had become due to him, and then only to the extent of the amount payable and only until the amount is paid. The joint venture agreement imposed an obligation on Dover to make monthly payments to Awad equal to his share ( 18 pereent) of the net profits of the joint venture. Dover was in breach of its payment obligations, as no monthly payments were made to Awad since February or March of 2004. Awad was therefore a creditor of Dover. The crucial issue was whether Awad, as a creditor, should be recognized as a "complainant" for the purposes of the oppression remedies under the $O B C A$.

Dover argued that the relationship between the parties was constituted by contract and that it was open to Awad at the time of the negotiation of the joint venture arrangement to seek contractual protection on the matters that were the subject of the claim for oppression remedies.

If the only issue was whether Dover had failed to make a payment that was due, then it would be questionable whether an oppression remedy should be available. The issue went beyond that in this case. Dover was asserting a right to a set-off that potentially applied to its future payment obligations out of joint venture profits. It was not clear that damages determined at a particular time, while the joint venture relationship and its attendant obligations remained in force with continuing affect, would necessarily be an adequate remedy. The Court concluded that, in this case, it was unfair that the payments to Awad were being withheld and Awad ought to be recognized as a "complainant" for the purposes of the oppression remedies.

The Court held that Dover had acted oppressively against Awad by making improper deductions in calculating profits on account of purported financing costs and operating expenses. An accounting was required to determine the amounts due to Awad with respect to the joint venture, and a valuation was also required of Awad's interest for the purposes of Dover's buy-out of his interest.

But the case did not end there. Dover made a subsequent application to the judge to introduce fresh evidence, suggesting that Awad was taking steps to dispose of his assets in an effort to insulate himself from liability. Dover submitted that, in light of the evidence, the finding that Dover's conduct was oppressive should be reconsidered. The Court allowed the application and held that there should be a trial on the issue of whether Dover's conduct was oppressive in the circumstances.

\section{COMMENTARY}

This case is potentially significant in its recognition that the oppression remedies under modern business corporation statutes in Canada may be available to redress complaints of minority interest holders in oil and gas joint ventures. The Ontario Superior Court recognized 
that merely being a participant in a joint venture does not, in itself, constitute a participant as a "creditor" within the scope of the oppression remedy provisions. If a distribution of profits from the joint venture has become due and payable, however, and the court considers the minority interest holder in the joint venture to have been treated unfairly or oppressively, then, at least in Ontario, a court will recognize the minority interest holder as having standing to invoke the oppression remedies under the $O B C A$. These remedies are far-reaching in scope and include a court's power to order the purchase and sale of the complainant's interest in the company.

\section{B. DIRECT ENERGY MARKETING LIMITED V. KALTA ENERGY CORP. ${ }^{107}$ \\ 1. BACKGROUND}

Assets of oil and gas joint ventures are commonly owned jointly by the working interest owners. In order for the assets to be subjected to a valid security interest, all of the working interest owners may be required to either join in the security agreement or explicitly authorize the operator to grant a security interest on their interests in the assets. This case illustrates that a lease of joint assets made by the operator, without the other working interest participants joining in or authorizing the lease, may be found to be invalid.

\section{FACTS}

Kalta Energy Corp. (Kalta) was the operator of seven wells in Alberta jointly owned by a number of working interest owners. The operation of six of the seven wells was governed by a joint operating agreement which incorporated the Canadian Association of Petroleum Landmen 1974 operating procedure (1974 CAPL Procedure).

Seven separator packages were required for the operations. In November 1999, Kalta issued authorizations for expenditure (AFEs) to its working interest partners. The AFEs included the cost of the separators. The separators were supplied by Ultrafab Industries Limited (Ultrafab) pursuant to oral purchase agreements. The working interest partners paid the operator for their shares of the cost of the separators pursuant to cash calls from the operator, and each of the working interest parties acquired an undivided interest in the separators.

After the equipment was delivered, Kalta entered into a lease agreement with Ultrafab, called the "Equipment Rental Purchase Agreement," with respect to the seven separators. Under the agreement, Kalta was obligated to pay rent for the separators, and title to the equipment remained with Ultrafab during the term of the agreement or until Kalta exercised its option to purchase the separators. By June 2000 , Kalta was unable to meet its liabilities and went into receivership. 


\section{DECISION}

The working interest partners all held undivided interests in the separators. Property in the separators had passed from Ultrafab to Kalta and the working interest owners prior to the attempt to transform the sale of the separators into an equipment lease agreement.

Separators are "goods" under the Sale of Goods Act. ${ }^{108}$ In a situation involving the sale of future goods by description, property passes when the goods are delivered to a carrier for the purpose of being transported to the buyer. In this case, property in the separators passed at the time they were delivered to the trucking company retained by Kalta. This was prior to the execution of the equipment rental purchase agreement.

The 1974 CAPL Procedure, which governed the relationship between Kalta and its working interest partners, provided that equipment held on joint lands for the joint account was held as tenants-in-common. Accordingly, when Kalta purchased the separators for the joint account, each working interest partner obtained a proportionate interest in the separators.

The property in the separators having transferred to the working interest partners, Kalta could only enter into an equipment lease if it had authority from its partners to do so. While the 1974 CAPL Procedure gave Kalta control over management, development, and operation of the joint lands, the authority did not include the ability to sell or transfer interests in joint account assets held by other partners without notice or consent.

The equipment lease entered into by Kalta and Ultrafab was a transaction out of the ordinary course of business. Kalta had no authority to sell back to Ultrafab the whole of something in which it only held a percentage interest. Because the sale purported to be for the entirety of the interest, the lease agreement was void for mistake.

\section{COMMENTARY}

The lesson here is that a creditor who wants to take security on the assets of a joint venture must be careful to ensure that the operator has the authority to grant the security interest on behalf of all of the project owners or, alternatively, require that all the joint owners join in the security agreement.

XIII. LeASES

A. WEBSTER V. BROWN ${ }^{109}$

I. FACTS

In 1990, the Websters purchased a piece of farmland for which four surface leases had been granted. Penn West Petroleum Ltd. (Penn West), one of the defendants, is the current 
lessee. A previous owner of the land, James Brown, granted the leases in 1949 to Penn West's predecessor. In 1964, the land was transferred from the estate of Mr. Brown to a Mr. Mitchell and a Mr. MacDonald. The latter two men proceeded in 1968 to "assign and direct that all rentals, proceeds and payments due and accruing due subsequent to the first day of July, A.D., 1964, pursuant to all surface leases and renewals thereof pertaining to the said land be paid to the assignee (Daisy Margaret Brown) so long as she does live, and on her death to her successors, heirs and assigns."110 $A$ valid caveat was registered against the land referencing the assignment in 2002 . Subsequent to the 1968 assignment, the various lessees, and eventually Penn West, paid the rental payments to Ms. Brown and, later, her estate.

The issue, essentially, is the ascertaining of who is entitled to the surface rental payments. The Websters claim the assignment was "purely contractual," and that it ended when the original assignors (Mitchell and MacDonald) transferred away fee simple title to the land in question. The Brown estate acknowledges the assignment did not create an interest in the land, but submits it is a chose in action that can be transferred independently of the land as long as new landowners have notice. In support of this argument, the estate's counsel referenced a number of cases with similar facts, such as Fleck v. Davidson Estase IIt and Sherman v. Ogonoski. ${ }^{112}$ Both cases were distinguished on the facts by the trial judge.

\section{DECISION AND ANALYYSIS}

This decision gives insight into the co-application of numerous basic principles governing the law of assignments. Northland Bank $v$. Van de Geer ${ }^{113}$ held that a general assignment of rents does not create an interest in land and, therefore, a caveat cannot be filed to give notice of such an assignment. This position was changed with amendments to the Alberta Law of Property Act, ${ }^{114}$ but the Court specifically held that the new sections of the Law of Property $A C l$ would not apply for the purpose of legitimizing caveats that could not have protected interests in the land at the time of filing. The 1968 assignment at the heart of this dispute would fall into that category.

Canadian Crude Separators v. Mychaluk ${ }^{115}$ was presented by the Websters. The facts of that case are similar, and it applies Northland Bank. ${ }^{116}$ The Court concluded in Canadian Crude Separators that the assignment ceased to be operative when the successors in title to the reversion holder sold the land. The fact that the subsequent acquirers of the land, the County of Stettler, carried on making payments to the beneficiaries of the defendants was found to be immaterial. The Brown estate argued that Canadian Crude Separators should be read to suggest that the $\mathbf{2 0 0 2}$ caveat, filed after the declared invalidity of a 1971 caveat, operated to bring the assignment under the law as exists after the 1985 amendments to the Law of Property Act. This argument, unsupported with reasons, was rejected, as the Law of Property Act lacks retrospective operation.

\footnotetext{
110 hid. al para. 6.

111 [1997] 2 W.W.R. 60 (Sask. C.A.).

II: (1993), 143 A.R. 71 (Q.B.).

11) (1986). 75 A.R. 201 (C.A.) [Northland Bank].

I1t R.S.A. 1980, c. L-8, as am. by S.A. 1985 , c. 48 , s. 4.

IIS (1997), 207 A.R. 81 (Q.B.) [Canodian Crude Separarors].

Ilh Stupra nolc 113.
} 
The Court decided that the Websters were entitled to rental payments from 2001 onward, and the assignment was declared invalid. This decision clarified the application of Canadian Crude Separators and affirmed the understanding that rental payment reservations after a transfer of title do not create interests in the subject property. In so doing, the Court limited the lifetime of general reservations of rents or other profits.

\section{B. KERR V. PANCANadian PETROLEUm Lto. 117 \\ l. FACTS}

Mr. and Mrs. Kerr owned land in Saskatchewan upon which PanCanadian Petroleum Limited (PanCanadian) operated two oil well sites. In 1999, the Kerrs were approached by PanCanadian to amend a surface lease for the construction of a horizontal well. In the course of these negotiations, the Kerrs discovered surface lease payments on the existing wells had been paid to Dorothy Kerr, Mr. Kerr's cousin, for over a decade. She was in receipt of the payments after the passing of her father, Joseph Kerr, who had sold the land to his brother, Robert Kerr (Mr. Kerr's father), in 1968. The Kerrs demanded that they receive surface lease payments, in response to which PanCanadian noted an obligation on the part of the lessor to notify PanCanadian of any disposition of his interest. Eventually, however, PanCanadian accepted a document produced by the Kerrs showing Mr. Kerr's father had registered a caveat in 1975, it being implied that he must have had title to the land to file the caveat. Encouraged by this, the Kerrs then demanded PanCanadian compensate them for all payments made since Mr. Kerr became titleholder of the property in 1975.

At a meeting to resolve the dispute in 2000 , Mrs. Kerr produced a document entitled "Memorandum of Agreement," dated 1975. It was an option to purchase granted by Mr. Kerr back to his father, admittedly to limit his wife's interest in the event their then-recent marriage did not last. A clause of this document referenced a March 1967 agreement for sale between Robert Kerr and Joseph Kerr, which appeared to reserve the surface lease payments to himself. The discovery of this document led PanCanadian to suspend all payments to the Kerrs. The Kerrs then filed a statement of claim in October 2000, alleging, amongst other things: (1) that they were owed damages for failure to pay the surface lease rentals from the date Mr. Kerr became the registered owner of the land; (2) that they were not bound by the reservation of Joseph Kerr, as he had failed to file a caveat on the land; and (3) that the surface lease agreements of 1967 violated the rule against perpetuities. PanCanadian filed a counterclaim for the amount paid to the Kerrs in 1999 and a third party claim against Dorothy Kerr, claiming indemnification from her in the event PanCanadian was liable for payment of surface lease rentals to the Kerrs. Dorothy Kerr filed a fourth party claim against the Kerrs seeking a declaration that they were bound by the reservation agreement. The dispute was highly acrimonious. 


\section{DECISION AND ANALYSIS}

The focal issue was whether or not the Kerrs were bound by the reservation agreement. Justice Chicoine of the Saskatchewan Court of Queen's Bench, interpreted the Land Tilles $A c t, 2000^{118}$ to decide the reservation did create an interest in land. The well-respected principle that caveats protect, as opposed to create, interests in land was also applied, defeating the Kerr's argument that the lack of a caveat extinguished the reservation. The issue of whether or not the Kerrs were bound by the reservation turned on notice; the 1967 lease agreement being referenced in the 1975 option to purchase convinced the Court that the Kerrs did, in fact, have notice of the reservation. The Court also found the rule against perpetuities was not at issue in this case, as the interest in the land vested in the lessees upon execution. In addition, Chicoine J. felt there was no "detriment to society in general" 1 " if a surface lease should be renewed occasionally to accommodate further exploitation of the mineral wealth below the surface of that property.

The Court, holding that Dorothy Kerr's receipt of payments was valid, granted a recission of the 1999 contract with the Kerrs. Amounts paid during that period became payable to Dorothy Kerr. As the 1967 reservation employed specific wording limiting the payments owed to rents, other payments such as compensation for nuisance or inconvenience would remain payable to the Kerrs; recission would have the effect of returning the parties to their original positions and would not interfere with that arrangement.

\section{Pipelines}

A. TransCanada Pipelunes Ltd. v. Canada (National Energy Board)

\section{FACTS}

This was an appeal of a National Energy Board (NEB) decision from February 2003. The Board is responsible for the regulation of interprovincial natural gas pipelines. The TransCanada Mainline, the pipeline at the center of this litigation, is considered a "Group 1" Pipeline. Its operating results are regularly monitored by the NEB. Tolls are charged for transporting gas through the pipeline, and are regulated by the NEB on a cost of service basis. This involves, amongst other things, estimating the costs to be incurred by the Mainline at the beginning of each fiscal year. The Mainline's cost of capital is the principal cost it accrues.

The rate of return on equity is a component of the "cost of capital" calculations. The NEB uses a methodology whereby they estimate a risk-free rate based on a government bond and add a risk premium to account for the risk associated with equity investment in such a pipeline. The composite rate of return is then multiplied by a factor assigned according to the relative risk of investment in each particular pipeline operation. The utility costs of service 
represent the product of that multiplication added to operating expenses. The total costs are then allocated amongst the utility's customers.

In 1994, the NEB began a consultation process with a view to fixing the cost of capital for Group I pipelines, and establishing a rigid structure for adjusting the model. They issued a decision in March 1995 fixing the Mainline's return on equity for the 1995 year at 12.25 percent, based on certain assumptions. This formula was adjusted for several subsequent years of estimation. By 2001, the appellant was of the opinion that the application of the formula was understating its required rate of return on capital. Without delving into the complexities of the accounting calculations, the appellant was of the view that a formula should be applied that did not take into account customer or consumer interests in determining the Mainline's rate of return on capital. Such a formula was suggested when the NEB held hearings to deal with the appellant's complaints in 2002. The issue for appeal is whether or not the NEB erred in that consideration.

\section{DECISION AND ANALYSIS}

The Board is not required by statute or regulation to adopt any specific methodology in determining tolls and fees. The only requirement of the National Energy Board $A c t^{121}$ is that the tolls be just and reasonable. ${ }^{122}$ Similarly, the NEB's authority to make determinations as to its own tolls is not limited by statute or regulation. It is established law, however, that tolls which reflect a "fair return" on capital will be just and reasonable to both the Mainline and its users. TransCanada Pipelines Ltd. (TransCanada), conceding that it did not object to customers having input into the NEB's cost determinations, objected to the Board taking the impact of tolls on customers into account in determining the Mainline's cost of equity capital. When final tolls are being decided, TransCanada argued, the impact of the tolls on customers may be a relevant consideration, the weight of which is to be debated.

This argument was accepted by the Court as being in keeping with the "fair return" principle. "The cost of equity capital," the Court observed, "does not change because allowing the Mainline to recover it would cause an increase in tolls." 123 The risk associated to the Mainline is accounted for, the Court held, by adjustments to its deemed capital structure. Accordingly, the cost of providing the fair rate of return to its investors does not impact the tolls of consumers, at least not directly.

The Court observed, however, that the NEB has mechanisms in regulating how the utility recovers its costs (in instalments, over time, efc.) to prevent fluctuations in the tolls from unduly affecting the consumers of the pipeline's service. 


\section{B. GARY TONKS LTD. V. TERASEN GAS ${ }^{124}$}

\section{FACTS}

This case centres on whether gas utilities, or other pipeline operators, are responsible for upgrading their lines in the event of changes to the land surface use. The parties are successors in title in an easement dating from 1959. At that time, a utility (predecessor of the defendant, Terasen Gas) was granted an easement for the installation of a pipeline on property owned by Canadian National Railways (CNR). The land was vacant, although CNR was considering the construction of a spur line over the parcel. The amount of $\$ 2475$ was paid in consideration for the easement. The plaintiff, Gary Tonks Ltd. (Tonks), came into possession of the lot in 1997 and desired to use the surface area of the right of way as a commercial storage yard. To do so, the plaintiff needed to add landfill to the property in compliance with a regulation related to the 100-year flood plain of the river adjacent to the easement. This regulation, or any contemplation of the flood plain, did not exist at the time of the easement's negotiation. The defendant, a utility, informed the plaintiff of dangers associated with the application of fill on the surface of the easement. A real risk of compromising the integrity of the pipeline was presented by Tonks' improvements since the pipeline was not designed to bear the weight of additional fill or construction.

The plaintiff sought a declaration that the defendant was in breach of the easement agreement, and that the easement itself constituted a private nuisance against the plaintiff's enjoyment of his property.

\section{DECISION AND ANALYSIS}

Section 3(b) of the easement agreement required the utility to, "insofar as it is practicable to do so ... maintain all the pipe lines constructed hereunder so as not to interfere with the drainage or ordinary cultivation and use of the land."12s The plaintiff argued the "ordinary cultivation and use of the land" meant any use that would have been ordinary in 1959, industrial purposes included. The plaintiff referenced communications made in the process of negotiating the easement between CNR and the utility indicating that both parties had contemplated possible future uses of the land. The plaintiff added that "practicable" meant "possible," excluding any consideration of the feasibility of maintaining the pipeline. The Court, however, agreed with the defendant, who submitted that ordinary use meant the status of the land at the time the easement was granted, being fallow; and practicable clearly could not be read to exclude any consideration of costs to the utility. Although the Court decided the language of the easement was clear and unambiguous, brief reference was made to the supporting documents relied upon by the plaintiff. They demonstrated a desire by CNR to preserve a right of compensation from the utility for the construction of a spur line across the property in such a fashion that the pipeline would not be affected. Justice Rogers understood the spur line discussions to be negotiations of an exception to the general rule, which is that the utility would not be forced to compensate CNR for any development on the easement property made impossible by the presence of the pipeline. As a result of this decision. 
Terasen was found not to be responsible for upgrading the pipeline to withstand the weight of the landfill, nor were they obliged to compensate Tonks for lost use of the land.

The nuisance argument was dismissed through an analysis of the classical principles of an easement. Foremost among these is the principle that the enjoyment of the plaintifrs property by himself is subject only to the right of the utility to enjoy its privileges; the fact that any industrial activity on the land might infringe on that right does not negate the hicrarchy of rights established by the easement agreement.

\section{COMMENTARY}

This case gave the Court an opportunity to reflect on the relative responsibilities of the parties to an agreement of this type. It also allowed the Coun to re-affirm both the traditional understanding of easement rights - the right to enjoy one's land subject to the easement, regardless of the scope of that subjection - and to define "practicable" and "ordinary use of the land," terms used in similar agreements and contexts governing the use or misuse of land over pipelines.

\section{NON-COMPETITION}

\section{A. IMPERIAL OIL V. H.H.L. FUELS LTD. ${ }^{126}$}

\section{BACKGROUND}

Non-competition and non-solicitation clauses are widely used in a variety of contractual situations including asset and share purchase agreements, employment and consulting contracts, and agency and distribution contracts. This case demonstrates the types of practical problems that are faced in attempting to enforce non-competition and non-solicitation clauses. The problems are two-fold. First, the non-competition or non-solicitation clause must itself pass the threshold test of not being, in the view of the court, an unreasonable restraint of trade. Second, the evidence of breach will likely have to be clear and compelling before a court will provide redress.

\section{FACTS}

Herman Levesque entered into an agency agreement with Imperial Oil (Imperial) in 1970 for the distribution of home heating oil in the Edmunston, New Brunswick market arca. In 1973, he incorporated H.H.L. Fuels Ltd. (HHL), and this company became the agent in place of Herman Levesque. HHL entered into an agency sales agreement with Imperial in 1985. Herman Levesque signed this agreement in his capacity as director of HHL, but not in his personal capacity.

In late 1997, Imperial decided to change its agency distribution arrangements in New Brunswick and other parts of Canada. The plan in New Brunswick was to see approximately 14 agencies reduced to four or five "super" agencies. Herman Levesque did not support the 
plan and later decided to retire. Paul Levesque, Herman's son, decided to start up his own home heating oil distribution business.

In 2000, Paul Levesque incorporated Pétrole P. Levesque Fuels Inc. (PPL) to operate a home heating oil sales business. PPL applied to the Royal Bank of Canada for financing. The application for financing indicated that PPL intended on taking over the market previously serviced by HHL.

By August 2000, lmperial concluded that it was losing a substantial number of customers in the Edmunston area, and it had concerns that PPL or Paul Levesque had obtained HHL's fuel customer list. Imperial brought an action claiming that HHL had breached the nonsolicitation/non-competition covenants in cl. 9.08 of the 1985 agency agreement. Imperial also claimed that the defendants had breached fiduciary duties and duties of fidelity owed to Imperial, had committed a breach of confidence, and had induced Imperial's customers to breach their contracts.

The 1985 agency agreement contained the following provision with respect to solicitation and non-competition:

9.08 Agent agrees that he will not for a period of twelve (12) months after the expiration or other termination of this Agreement, directly or indirectly, as principal, agent, partner, employce or otherwise howsoever, solicit orders for or supply within the market area any products then being sold by IMPERIAL within the market area, to any person, firm or corporation who purchased such products within the market area either as an assigned or as an unassigned customer within the period of twelve (12) months preceding the date of expiration or termination of this Agreement. ${ }^{127}$

\section{DECISION}

Imperial's claim was dismissed. The Court began its analysis by considering whether the restrictive covenants in the agency agreement were enforceable. In Elsley v. J.G. Collins Insurance Agencies, ${ }^{128}$ the Supreme Court of Canada determined that a restrictive covenant in restraint of trade is enforceable only if it is reasonable between the parties and with reference to the public interest. In Wimnipeg Livestock Sules LId. v. Plewman, ${ }^{129}$ citing Friesen v. McKague, ${ }^{130}$ it was held that an employer has a proprietary interest in preserving its customers after the termination of an employee who is perceived, or is likely to be perceived, by customers as the "personification" of the employer company.

In determining whether a general non-competition clause is reasonable and enforceable against a former employee, the court will consider a number of factors including:

(1) the length of service of the employee; 
(2) the amount of personal service to clients;

(3) whether the employee dealt with clients exclusively;

(4) the extent of confidential or intimate knowledge of clients gained by the employee;

(5) the extent of the employee's influence over clients;

(6) whether clients have switched without any direct solicitation; and

(7) the nature of the employer's business. ${ }^{131}$

The clause in this case (clause 9.08 of the agency agreement) stated that the sales agent (HHL) agreed not to solicit orders for or supply any products then being sold by Imperial. The Court determined that this clause was reasonable and was valid and enforceable as between HHL and Imperial, the only parties to the contract.

The Court determined, however, that there was insufficient evidence that Herman Levesque, the directing mind of HHL, directly or indirectly solicited orders or supplied customers of Imperial in breach of clause 9.08. The Court stated that no evidence was produced by Imperial of any former customers of HHL being solicited by HHL or Herman Levesque on behalf of PPL.

The Court also rejected Imperial's claim of breach of fiduciary duty. The Court stated that a "key ingredient" to establish a fiduciary duty is vulnerability. ${ }^{132}$ The Court also stated that the general rule is that fiduciary duties do not arise in a manufacturer-dealer relationship unless there are "exceptional circumstances." ${ }^{\text {"133 }}$ The Court was of the view that although Imperial was in a vulnerable position with respect to customer contacts and relations, this was not an exceptional circumstance because this type of vulnerability existed in every agency situation. Imperial did not feel it was necessary to protect itself by including standard clauses in the agency agreement to prohibit the type of actions that were taken by the defendants in this case. Accordingly, there was no fiduciary duty owed to Imperial by HHL, PPL, or Herman or Paul Levesque.

The duty of fidelity was examined in the cases of G.M.G. Fish Services v. McGratron ${ }^{134}$ and Barton Insurance Brokers Lid. v. Inwin. ${ }^{135}$ In Barton, a former employee moved to a new company and was asked to go through the local phonebook to try to recollect people she knew as customers of her former employer, and to then solicit their business. She obtained the business of about 230 customers of her former employer. The employee was not bound by a restrictive covenant to her former employer. The former employer sought an injunction and damages for wrongful appropriation and use of confidential information. The Court, in that case, found that the defendant did not owe a fiduciary duty to her former employer and 
she was entitled to recollect the names of people she had formerly dealt with using a directory and to solicit their business.

The situation with Paul Levesque in this case was similar. Prior to starting up his own business, Paul Levesque had been only a part-time employee of HHL. He was not a senior officer. A claim for a breach of fidelity or a breach of fiduciary duty could not be founded on the conduct of Paul Levesque. The evidence did not support a claim of breach of fiduciary duty, breach of fidelity, or breach of confidence by HHL or Herman Levesque even though they were in a different position than Paul Levesque. Although Herman Levesque was a senior manager of HHL (and its directing mind), the court was not convinced that Herman Levesque held any management position in PPL, solicited customers for PPL, or utilized confidential information received from Imperial to assist PPL. Although Herman Levesque provided financial support to PPL, the Court did not consider this to be a breach of s. 9.08 of the agency agreement with Imperial or a breach of any fiduciary duty or duty of fidelity.

\section{COMMENTARY}

A number of points are noteworthy from this case. First, although there was no employer/employee relationship between Imperial and its sales agent, the Court did refer to the factors considered by the courts in employment situations in determining whether the non-competition clause was reasonable and enforceable. These factors include the length of service of an employee, the nature of the relationship of the employee with customers, and the extent of confidential or intimate knowledge of customers gained by the employee. These factors, it is submitted, do seem to provide an appropriate framework to analyze the reasonableness of non-competition clauses in the context of the type of sales agency relationship that existed in this case.

Second, the case serves as a reminder that it is critically important when dealing with a small closely held company (like Imperial's sales agent in this case) to ensure that the principal of the company is made a party to the non-competition agreement and signs it in his personal capacity. The failure by Imperial to do so in this case precluded Imperial from being able to assert a claim in contract against the very person who posed the most significant competitive threat to Imperial's business in the region.

Third, this case illustrates the importance of taking care in drafting non-competition clauses to ensure that they are specific in describing the types of activities that are prohibited. In this case, the non-competition clause only prohibited the solicitation of orders and the supply of competitive products. The clause did not prohibit the "usual" types of activities that are prohibited by a standard non-competition clause such as providing financing, owning an interest in a competitive business or participating in its management, or allowing the use of the individual's name. The absence of this type of clause proved to be significant in this case. Not only was Imperial unable to show any specific activity that violated an express prohibition in the non-competition clause but, to make malters worse, the Court suggested in its decision that the failure by Imperial to insist on a standard non-competition clause indicated that Imperial did not consider itself to be in a vulnerable position that could give rise to a fiduciary duty by the sales agent or its principal. 
Finally, the case shows that fairly clear and compelling evidence of a prohibited activity will likely be required by a court in order to succeed in a claim for breach of a noncompetition agreement or breach of fiduciary duty. In this case, the Court seemed unconcerned by evidence (in documents provided to obtain financing) indicating that the new competitive business being started by Paul Levesque was relying on Herman Levesque for his experience and possible financial assistance. The Court also seemed unconcerned by the fact that letters had been sent to potential customers indicating that Herman Levesque was retiring and his business had been sold to the new company started by his son. The problem that Imperial faced with this type of activity was not so much proving that it occurred, but proving that the person engaged in the activity (in this case Herman Levesque personally) was prohibited from doing those things by virtue of a non-competition covenant or fiduciary duty by which he personally was bound.

\section{RoYalties}

\section{A. JAMES H. MEEK TRUST(TRUSTEE OF) V. SAN JUANRESOURCES (MEEK TRUST\#1) 130}

\section{l. FACTS}

In 1950, Mr. Howard Emery became the lessor of Crown petroleum and natural gas rights related to certain parcels of land. The lease was held beneficially for Hudson's Bay Oil and Gas Company Limited (HBOG). In August of that year, HBOG entered into a joint operating agreement with Canadian Delhi Oil Ltd. (Delhi) covering various lands including some of the parcels associated with the lease. The agreement granted Delhi the opportunity to earn a 50 percent working interest in the lease, following their drilling of certain wells. Pursuant to that arrangement, HBOG assigned a 50 percent working interest in the lease to Delhi under a Memorandum of Agreement in March of 1951. One year later, Delhi entered into a contract where Mr. Meek, the titular plaintiff, was granted a 3 percent overriding royalty (the Meek royalty) on any production that might arise from any of Delhi's interests in exchange for various exploration work done by Mr. Meek (the Meek Trust).

In due course, Delhi became Sulpetro Ltd. (Sulpetro), which entered into a farmout agreement with San Juan Resources Ltd. (San Juan). San Juan then assigned the rights and obligations it acquired under the farmout to UniGlobe International Energy Corporation (Uniglobe), retaining a 4 percent overriding royalty. In the original joint operating agreement, cl. 10 specified the procedures for joint and independent drilling operations on the lands. It stated that, should one of the parties decide to drill, the other party may participate in the drilling by paying its share of the costs. If the other party does not participate, the drilling party is entitled to have conveyed to it the non-participating party's full interest in the quarter section where the well was drilled. In July 1987, San Juan and UniGlobe entered into a letter agreement stating that, in the event HBOG elected not to participate in the drilling of the well, San Juan would obtain the right (but not obligation) to participate in respect of any interest that might be forfeited by HBOG's non-participation. 
October 1987 saw Sulpetro, on behalf of San Juan and UniGlobe, send independent operations notices to HBOG indicating their intentions to drill a number of wells on certain subject lands, and inviting HBOG to participate. HBOG declined, reserving rights to participate after-the-fact upon payment of the appropriate penalty. Immediately after this communication, Sulpetro went into receivership. Imperial Oil Resources (Imperial), a codefendant, acquired via Sulpetro's receiver their interest in the lands subject to the joint operating agreement. Imperial, Sulpetro, and the owners of the Meek royalty entered into a novation agreement under which Imperial assumed Sulpetro's obligations in regard to the subject lands.

In December 1987, a well was commenced on NE Section 35, a section of the subject lands. After receiving notice, HBOG did not indicate whether they wished to co-participate with San Juan after-the-fact, and their interest in NE Section 35 was forfeited. Exercising its right of first refusal, San Juan acquired the forfeited interest. In 1994, an agreement was reached between Imperial and San Juan, whereby it was conceded that San Juan owned the Sulpetro interest in NE Section 35 under the farmout agreement, and Imperial's only interest in that subject was Sulpetro's retained gross overriding royalty. Imperial had not, however, assigned the lease to San Juan. Through a process of bankruptcies and transfers, the situation on NE Section 35 was settled as follows: Imperial was the lessee of the Crown petroleum and natural gas rights, and held a convertible gross overriding royalty on the production from a 50 percent working interest originally held by Sulpetro; San Juan owned a 75 percent working interest and was the operator of record and holder of the well licences; Hampstead Trust Corporation (Hampstead) owned a 25 percent working interest; and Petro Canada Ltd. held a 1.25 percent gross overriding royalty on the production from the 50 percent working interest originally held by Sulpetro. The wells on the section in question formed part of a unit operated by ConocoPhillips.

The applicants, being the beneficiaries and trustee of the Meek Trust (partly constituted by the Meek royalty), sought certainty on the subject of whether the Meek royalty was an interest in land. In addition, the applicants inquired as to what interests the Meek royalty attached, and whether the Meek royalty was subject to deductions for processing and trucking costs.

\section{DECISION AND ANALYSIS}

The applicants asserted that the Meek royalty was an interest in land, and were seeking a declaration to that effect. San Juan took the position that the Meek royalty was not an interest in land and that it had no liability, as the royalty was merely a personal obligation between Delhi and Mr. Meek to which San Juan was a stranger. Alternatively, they argued that the Meek royalty could not attach to the 25 percent working interest San Juan acquired through HBOG's forfeiture and, if the royalty does attach to the whole interest, that Hampstead must pay 25 percent of it. Hampstead supported this position. Imperial, for its part, admitted that the novation agreement imposed a contractual obligation upon it to pay the Meek royalty to the applicants, and supported the position that the royalty was an interest in land. San Juan and Hampstead were thus liable for the royalty in proportion to their respective working interests. Imperial indicaled that it would be seeking indemnity from San Juan for its obligations to the Meek Trust in a future application. 
In a reasoned judgment, it was concluded by LoVecchio J. that the Meek royalty was not an interest in land. He applied a test approved by the Supreme Court in Bank of Montreal $v$. Dynex Petroleum Ltd. ${ }^{137}$ to determine if this type of gross overriding royalty forms an interest in land. Under this test, the Meek royalty would be an interest in land if:
The language used in describing the Meck Royalty is sufficiently precise to show that the parties intended the royalty to be a gramt of an interest in land, rather than a contractual right to a portion of the oil and gas substances recovered from the land; and

The interest, out of which the Meek Royalty is carved, is itself, an interest in land. ${ }^{138}$

The original Delhi interest was clearly an interest in land, satisfying the second part of the test. The granting provision of the Meek royalty agreement read as follows:

Delhi hereby sells, assigns, conveys, transfers and sets over unto Meek a gross overriding royalty in the amount of three percent (3\%) of all oil, gas and other hydrocarbons which may be produced. saved and marketed from any and all lands described in Schedule " $A$ " ... under and by vinue of the agreements attached as Exhibits 1 to 10 inclusive of said Schedule "A". 139

Justice LoVecchio, considering a series of relevant cases, concluded that in the context of the oil and gas industry, the fact that this royalty was payable out of production should not be a determinative factor, indicating that this royalty was merely a contractual payment and not an interest. Several other clauses suggested to him, however, that the royalty was to be a payment obligation. Clause $v(2)(a)$ suggested that the royalty shail be

satislied hy payment by Delhi to Meek in Canadian funds ... ol Meek's proportionate share of the proceeds of sale of production of oil, gas and related hydrocarbons saved, recovered and marketed from the lands. ${ }^{140}$

The Meek royalty agreement, he continued, did not permit the royalty owners to take their royalty in kind, indicating a personal right. The fact that, if the royalty owners were "passive," they could not themselves cause the extraction of the hydrocarbons (legally) also suggested a right in personem in place of a right in rem. Justice LoVecchio countered the suggestion that the words "sells, assigns, conveys, transfers and sets over" represented conveyancing language by declaring them not sufficiently precise to create an interest in land, particularly when the balance of the argument favouring a personal right is considered.

Quoting a recital from the Meek royalty agreements, it was noted that the words "has acquired or may be entitled to acquire" were used to clarify the interests Delhi may have had, to which the royalty attached. This was taken to indicate the royalty agreement contemplated further growth of the interest. The granting clause (quoted above) further emphasized that the Meek royalty was calculated based on Delhi's working interest, whatever it may be at any given time. The agreement also considered the forfeiture and refusal provisions of the 
joint operating agreement, which preceded it. To quote LoVecchio J., the various changes in working interest and introduction of new stakeholders through later transactions and receiverships meant " $[t]$ he world was simply unfolding as the words [of the Meek royalty agreement] had contemplated." 11

Critically, on the subject of the 25 percent working interest acquired and eventually sold to Hampstead by virtue of HBOG's refusal and forfeiture, the Court held that San Juan had no independent right to acquire those interests. This excluded them from the operation of the Meck royalty, as they flowed through the Delhi chain of title. San Juan's interest arose thanks to the terms of Delhi's agreement. It was therefore concluded that the Meek royalty was to be calculated based on the entire working interest, of which San Juan possessed 75 percent and Hampstead 25 percent.

\section{B. JAMES H. MEEK ESTATE V. SAN JUAN RESOURCES (MEEK TRUST\#2)}

The Meek estate litigation was divided into two parts. The first trial, addressed above, dealt with the issue of whether the Meek royalty was an interest in land. The second trial is considered here. Three issues were outstanding: first, whether or not any claim by the applicants (the Meek estate and various related partics) for payment of arrears due more than two years before the original filing date was statute-barred; second, whether the applicants were entitled to interest on any arrears payable and its means of calculation; and third, whether or not Imperial was entitled to be indemnified by the respondent, San Juan, for any arrears found to be payable by Imperial.

Justice LoVecchio, in considering the first issue, reviewed the Limitations $A \mathrm{Ct}^{143}$ and debated whether the applicants knew or ought to have known of their claim before the twoyear period. After a thorough review of the facts, he concluded that the applicants had no actual knowledge of the facts giving rise to their claim, and no situation arose which ought to have alerted them to it. The applicants first had the opportunity to learn of their claim via correspondence from Imperial in May 2002, informing them of their status as potential litigants. The Court concluded, using this test, that no part of the applicants' action was statute-barred.

In considering the interest issue, the respondents argued that interest is generally ordered to be payable as a punitive measure against the payer. As punishment was not an issue in this case, San Juan submitted interest should not be awarded. The respondents, with the agreement of the Court, suggested that interest be awarded presently to compensate the claimants for the non-use of their money. Given the facts of this case, it was noted that two wells came online in 1988, allowing the respondents the use of their resource. The Meek estate had not been in receipt of the royalties and was not able to use the funds. Accordingly, LoVecchio J. made an order for simple interest to be paid. 
The indemnity claimed by Imperial was a considerably more difficult point of contention. San Juan's interest in the Meek properties arose by virtue of a farmout agreement, signed in 1987, with Sulpetro (Imperial's predecessor in this case). San Juan, as farmee, was required to participate in the drilling of a number of wells. San Juan would then receive 50 percent of Sulpetro's working interest, subject to a convertible royalty in favour of Sulpetro. The farmout agreement and the accounting procedure for their arrangement both clarified that San Juan was responsible for payment of the Meck royalty. San Juan and Imperial, assuming the rights and obligations of Sulpetro, disagreed on whether San Juan had met its commitment under the farmout agreement. Litigation was avoided thanks to a settlement agreement signed in October 1994. In that document, San Juan was given a discount on the value of the properties in question due to the Meek royalty. Imperial submitted that, as it received that benefit, it should not be permitted to deny the indemnity to Imperial.

San Juan argued it was unaware of the deduction made for the value of the Meek royalty. Justice LoVecchio looked at this point in a cursory fashion. focusing his attention on Imperial's internal calculations of the values used in the settlement. He did not appear to consider the Meek royalty. Nevertheless, the Court held that the farmout agreement, used by San Juan with other parties, treated the royalty as an encumbrance. Consequently, Imperial was entitled to be indemnified.

\section{R.W. MITTEN ENTERPRISES V. COMPUTERSHARE TRUST COMPANY OF CANADA ${ }^{14}$ \\ l. FACTS}

Mitten Enterprises, in the person of Robert Mitten (Mitten), is the titular to minerals on a parcel of land in a township near Red Deer, Alberta. In April 1950, he entered into a Gross Royalty Trust (GRT) agreement with the Prudential Trust Company Ltd. (Prudential) as trustee. The defendants are Prudential's eventual successors. At the time of creating the GRT agreement, there were no petroleum or gas leases in respect to Mitten's lands. In June 1950, Mitten, as lessor, entered into a freehold petroleum and natural gas (PNG) lease respecting the mineral title, eventually assigned by the lessee to Calvin Consolidated Oil. The lease had a ten-year term, to continue indefinitely so long as there was production of leased substances from the land. The Alberta Energy and Utilities Board (AEUB) confirmed that no wells were drilled on the land during that ten-year period, and the lease expired with the passing of time.

The issue was whether or not the GRT agreement expired upon the expiry of that PNG lease. The applicant argued that it should. The respondents asserted that the GRT agreement should be interpreted with respect to its treatment of "no lease" situations, as was the case when it was signed.

\section{DECISION AND ANALYSIS}

The reason for the differing treatments of the issue arose from the precedent case Guaranty Trust Co. of Canadav. Heatherington. ${ }^{\text {th }}$ The applicants asserted that the similarity 
between the GRT agreement addressed in that case and the Mitten agreement was such that Heatherington was an obvious precedent. In that decision, the Alberta Court of Appeal found that, as the GRT agreements at issue referred to specific leases, and as the term of those leases expired due to the passing of time (i.e., were not cancelled), the GRT agreements also expired. For the applicants, it was asserted that Heatherington was a binding precedentsetting case, and ought to guide the Court's decision in interpreting the Mitten GRT agreement.

The respondents, however, suggested that Heatherington turned on its own complicated facts, and the Court in that case was not obliged to consider the "no lease" situation as contemplated by the Heatherington GRT agreement itself. Therefore, they argued, they were not seeking to overturn Heatherington, as it could be distinguished on its own facts.

Justice Mason examined the subsequent decision of Barrett v. Krebs, ${ }^{146}$ which considered Heatherington. Although in that case the precedent was applied, Kerans J.A. of the Court of Appeal concluded that Heatherington did not establish a strict rule of interpretation. With this in mind, the Court in the present matter held that the wording of cl. 25 of the GRT agreement (and by extension, having accepted the similarities between the two GRT agreements, cl. 25 of the Heatherington agreement as well) permitted different results depending on whether or not leases had been undertaken with respect to the lands in question. In this case, however, seeing as the lease fell under all the operating provisions of the GRT agreement, it was held it expired at the moment of expiry of the initial lease.

\section{SPLIT TITLES}

\section{A. ANDERSON V. AMOCO CANADA OIL \& GAS ${ }^{147}$}

\section{BACKGROUND}

The final chapter in the protracted litigation relating to the respective ownership interests in petroleum (in liquid state) and gas in the same reservoir on "split title" lands was written by the Supreme Court of Canada in July 2004 when it dismissed an appeal from the Alberta Court of Appeal. At issue before the Supreme Court was the appropriate time at which to make the determination of ownership of gas and petroleum (in a liquid state) from a split title property, where one person owned the petroleum and another owned the non-liquid or gaseous hydrocarbons from the same reservoir.

\section{FACTS}

In the late 1800 s and early 1900 s, Canadian Pacific Railway (CPR) received grants of parcels of land from the government of Canada in connection with the construction of the Trans-Canada railway in western Canada. CPR subsequently sold much of the land to settlers, reserving the rights to petroleum (that is, for the purposes of such reservations, hydrocarbons in a liquid state in the ground) but not to the gas. This resulted in title to the 
ownership of hydrocarbons from these lands being "split" between petroleum rights owners and non-liquid, or gaseous hydrocarbon, rights owners.

Hydrocarbons exist in sub-surface pools in three forms: oil reservoirs, gas reservoirs, and mixed reservoirs. In the latter, prior to the penetration of the reservoir by drilling, the percentage of liquid and gaseous hydrocarbons is essentially fixed. Once drilling occurs, however, changes in this ratio occur because of a change in the temperature and pressure in the reservoir. Production causes the pressure in the reservoir to decline, and as this happens, some liquid hydrocarbons pass into a gaseous state within the reservoir. These newly formed gascous hydrocarbons are referred to as "evolved gas" or "secondary gas cap gas." "Free gas" or "primary gas cap gas" exists in a gaseous state in the reservoir at pre-drilling conditions. "Solution gas" is gas that was dissolved in liquid hydrocarbons in the reservoir prior to drilling, but which emerges in a gaseous state following changes in temperature or pressure.

The moment in time at which the phase or state of the hydrocarbon is examined becomes important because an underground pool may contain hydrocarbons in both liquid and gas phases. Before the pool is penetrated by drilling, the pressure and temperature remain relatively constant, as does the ratio of gas to liquid. Once the pool is penetrated by drilling, the pressure in the pool changes, usually decreasing. This has a number of effects. Of primary concern in this case is that some of the hydrocarbons in the liquid phase will evolve into the gas phase. Once this evolution happens, it is impossible to distinguish evolved gas from those hydrocarbons which were originally in a gas phase. The amount of hydrocarbons that change phase can be significant.

\section{DeCisions}

\section{a. Trial Decision}

Based primarily on the law as determined by Borys v. C.P.R. and Imperial Oil LId., ${ }^{1+8}$ the trial judge decided that the initial (pre-drilling) reservoir condition was the appropriate time to determine ownership. ${ }^{149}$ The trial judge confirmed that the rule of capture applied in Canada in "inter-tract" situations but not "intra-tract" situations.

\section{b. Alberta Court of Appeal Decision}

On appeal to the Alberta Court of Appeal, the appellants argued that ownership should be determined at the point the gas is captured at the well bore. The appellants argued that while Borys was determinative of where ownership occurs (in the reservoir), it was not determinative of when ownership is to be decided. They maintained that ownership of petroleum should be determined at the date the hydrocarbons are recovered from the ground and, as they emerge from the reservoir, in order to maintain consistency with the rule of 
capture. They argued that the phrase "in situ" means merely that ownership is to be determined by location, but not as at the time of initial reservoir conditions.

The Alberta Court of Appeal dismissed the appeal and upheld the decision of the trial judge. The Court of Appeal held that it is settled law in Canada that ownership is not determined at the surface. The Court accepted the following passage from the reasons of Parlee J.A. of the Appellate Division of the Alberta Supreme Court in the Borys case:

It is true that by change of pressure and temperature, gas is released from solution when the liquid is brought to the surface but such a change ought not to affect the original ownership.... In my opinion, all the peiroleum reserved, including all hydrocarbons in solution or contained in the liquid in the ground, is the property of the defendants who are entitled to do as they like with it, subject, of course, to the observance of all relevant [statutory] provisions and regulations. ${ }^{150}$

Anderson, and other "non-petroleum" owners, appealed to the Supreme Court of Canada for a determination as to the correct point in time at which the respective rights of the petroleum owners and the non-petroleum owners should be determined in relation to hydrocarbons produced from a well drilled on split title lands.

\section{c. Supreme Court of Canada Decision}

The Supreme Court of Canada dismissed the appeal, agreeing with the Alberta Court of Appeal that the time for determining the phase (or state) of a molecule of hydrocarbon, and the relative ownership interests, was at the time of the contract (i.e., at the time of the reservation of title) and not at the time of development of the well. The rationale for this is that the pools had not been interlered with by human contact at the time of the reservations.

It is the initial conditions of the pool that govern the relative ownership between the partics to the original contracts. Phase changes that occur once a pool is penetrated by drilling do not affect the ratio of hydrocarbons to which the petroleum owner and the nonpetroleum owner are each entitled:

The appellants submitted that Canada is not an ownership in situ jurisdiction and therefore no rights vest in hydrocarbons until they are reduced to possession. They relied on this ownership theory as support for their position that it is not until the time of possession that the phase of the hydrocarbon becomes important for determining ownership, because no one has any rights before that. This is the type of broad ownership theory that is not required to be determined in this appeal. Imespective of any other rights the parties may have in relation to the hydrocarbons in the ground, they chose to divide their interest by contract. It is not open to later argue that division was meaningless on the basis that no rights can attach until the substance is reduced 10 possession. When the substance, which was not in their possession at the time of the contract, is reduced to possession, the date and terms of the contract govern their relative entitlement. ${ }^{151}$ 
The Supreme Court was further of the view that the rule of capture should not apply to the determination of ownership where title depends on the phase (or state) of the hydrocarbons at the time of the contract:

\begin{abstract}
The appellants also relied upon the "rulc of capture" to suppor their position that cvolved gas belonged to them. The rule of capture developed as a rule of non-liability between owners of separate tracts of land. Since underground pools often extend beyond a single tract of land. it prevents $A$ from having a valid claim against $B$ when $B$ captures from under his land a substance that was originally under $A$ 's land. In Bongs, Lord Porter found this rulc would apply to oil and gas and $A$ 's only remedy was to drill its own well and hegin production. The unhindered application of this rule would lead to a race to produce, and because this uncontrolled development actually reduces overall hydrocarbon recovery, that rule has been subsumed by the regulatory environmental reserve and preservation provisions of legislation such as the Oil and Gas Conservation Act, R.S.A. 2000 , c. 0-6. ${ }^{152}$
\end{abstract}

\begin{abstract}
The rule of capture does not apply to the division of ownership hy phase as it does to divisions of ownership based on surface land ownership. Applying the rule of capture to parties who have agreed to divide their interest under the same tract of land would defeat the purpose of the contract. This is because if it applied, the party who reduced the substance to possession by drilling the well and producing the hydrocarbons would be entitled to all of them, and the other party would have no claim. At the lime the CPR sold the land to the settler they agreed to divide the property on certain lerms. To hold that either party could later take the other party's property with impunity would defeat the purpose of the resenvalion. ${ }^{153}$
\end{abstract}

The Supreme Court rejected the appellants' contention that dividing ownership based upon the original reservoir conditions leads to uncertainty because the original conditions in the reservoir could only be estimated. The Supreme Court endorsed the trial judge's conclusion that the entire industry relies on estimates of what is under the surface. These estimates, while not flawless, can appropriately be used as a guide to determine the amount of hydrocarbons owned by each party.

In the result, the petroleum owner was entitled to all hydrocarbons that were in a liquid state when the reservoir was untapped, regardless of their state when they were recovered. The non-petroleum owner was entitled to all hydrocarbons that were in gaseous state when the reservoir was untapped, regardless of their state when they were recovered. Phase changes that occur after a well is drilled do not alter the ratio of ownership.

\title{
4. COMMENTARY
}

The Supreme Court of Canada's decision endorses the view that the terms of the contract between the parties will trump any general rule of law regarding ownership of hydrocarbons. including the rule of capture. The rights of the liquid petroleum owners and the gas owners in a split title situation must be determined based on the contract from which their rights are derived. The contracts (that is, the reservations of title) in this case called for the ownership interests to be determined at the time of the contract (i.e., the time of the reservation of title). 
This point in time would be prior to the time the reservoir had been drilled and prior to the consequent change in the ratio of gas to liquid in the reservoir which occurs due to temperature and pressure changes from drilling. The practical difficulty of determining accurately the ratio of gas to liquid in the reservoir before drilling and extracting the hydrocarbons appeared not to be of significant concern to the Supreme Court. That determination could be made based on estimates used by the industry. It remains to be seen whether the next battleground may revolve around the reliability of estimates of pre-drilling ratios of gas and liquid where there are conflicting or inconsistent estimates.

\section{Taxation}

\section{A. IRVING OIL V. NEW BRUNSWICK (EXECUTIVE DIRECTOR OF ASSESSMENT) ${ }^{154}$ \\ l. FACTS}

The issues in this case are simple - so simple, it is surprising this case was the first to deliberate these facts. Irving Oil (Irving) was the owner of a massive refinery installation in Saint John, New Brunswick. At that facility, there were several large holding tanks, each equipped with mixers that kept the oil from separating. Irving sought a declaration that the holding tanks were part and parcel of its refinery operation, and therefore were not assessable as taxable property under the New Brunswick Assessment $A c t .{ }^{155}$ Irving argued that, as the tanks had mixers, and mixing was part of the refining process, the tanks were machinery and exempt from taxation. The Director of Assessment argued the main purpose of the tanks was storage, and that mixing was part of what was necessary to store oil; thus, they fell under the definition of assessable property.

The key issue, consequently, was whether or not holding tanks at a refinery are part of the refining process. Although assessment standards vary between jurisdictions, this case forms a touchstone for this point, should it be addressed elsewhere.

\section{DECISION AND ANALYSIS}

Under s. 1 of the $A c t$, assessable real property must have the characteristic of a shelter for people, plants, or moveable property, being stationed on land. Machinery stationed on land providing service to a building is also assessable. It was agreed, notes Clendening J., that the tanks have the characteristics of a structure. The question was whether that structure was a shelter for (in this case) moveable property, being oil. The Director of Assessment presented case law suggesting that oil tanks with fixed or floating roofs are considered to provide shelter for the oil and are assessable. ${ }^{156}$ Irving argued that items may have the external characteristics of a building and still be considered machinery, relying on New Brunswick Geographic Information Corp. v. Gilles, ${ }^{157}$ which held that dry kilns were machinery. Begin Lumber is part of a long line of authority suggesting a "primary purpose" test should be used 
for determining whether a structure is "machinery" or a "shelter." The Director of Assessments went on to argue that mixing was not the primary purpose of the tanks, seeing as the product entering the vessels was "stable." Irving replied by asserting that various finishing processes, including mixing, occur in the tanks, and each are necessary for marketability.

Following this argument, Clendening J. advanced his own precedent, Metals \& Alloys $C_{0}$. Lid. v. Ontario Regional Assessmen Commissioner, ${ }^{158}$ which developed the "integration lest" for making determinations as to the status of a structure. This test focused on the use to which the structure was put, as opposed to its physical characteristics. Metals \& Alloys employed the use of five questions: how is the item constructed? Why is it constructed in its shape? Does it look like a building? Is it built like a building? Does something happen within it that is an integral part of the manufacturing process?

Applying these questions, the Court was satisfied that the tanks were part of the refining process and were not assessable. Thus this case distinguished Cancoport, and set a liberal standard for future "grey areas" in determining the taxable status of parts of the refining process. 